\title{
EkoMiasto\#Środowisko
}

Zrównoważony, inteligentny i partycypacyjny rozwój miasta

pod redakcją

Agnieszki Rzeńcy

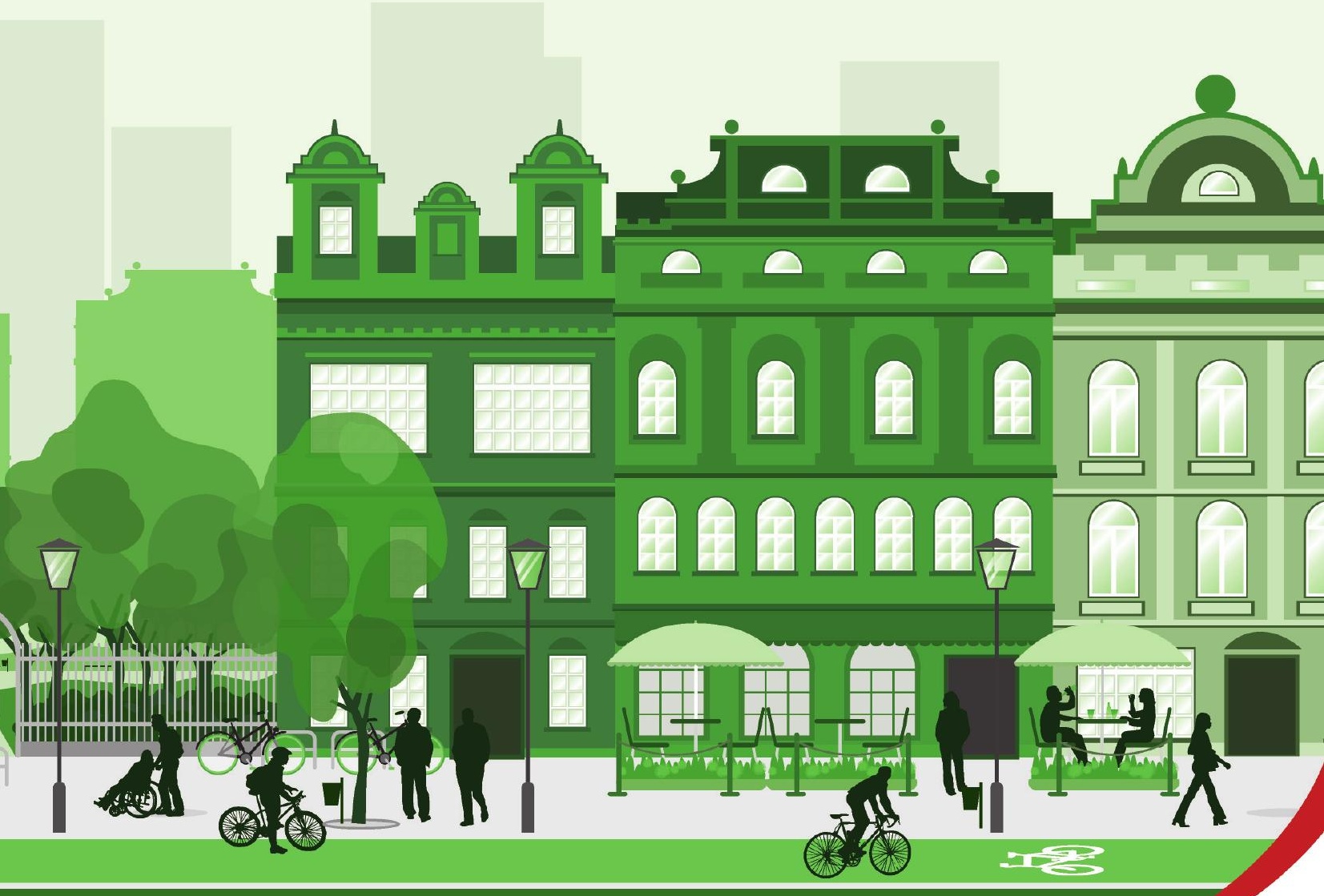


http://dx.doi.org/10.18778/7969-576-8.08

Małgorzata Burchard-Dziubińska*

\section{GOSPODARKA NISKOEMISYJNA W MIEŚCIE}
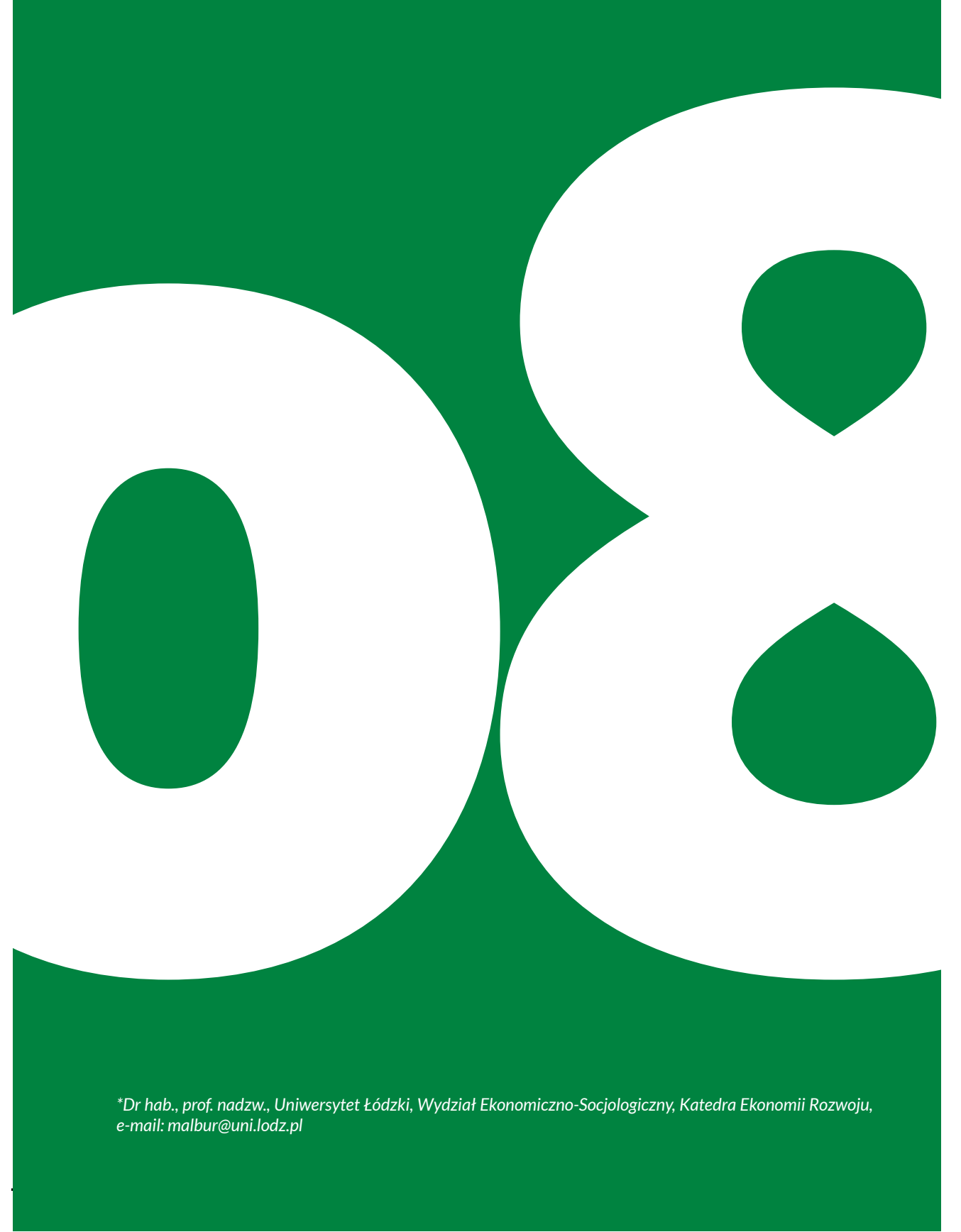


\subsection{Koncepcja rozwoju gospodarki niskoemisyjnej}

Koncepcja gospodarki niskoemisyjnej pojawiła się w związku z Ramową konwencją Narodów Zjednoczonych w sprawie zmian klimatu przyjętą podczas Szczytu Ziemi w Rio de Janeiro w 1992 roku. Wdrażanie postanowień konwencji, a zwłaszcza wytyczającego konkretne cele redukcyjne Protokołu z Kioto z 1997 roku, przebiega na arenie międzynarodowej dość opornie ze względu na znaczne różnice pomiędzy krajami w zakresie wielkości emisji, poziomu rozwoju i zdolności do sprostania redukcji emisji gazów cieplarnianych. Postulat ograniczenia emisji tych gazów w celu ochrony klimatu powiązano z rozwojem gospodarki niskowęglowej, co jest utożsamiane $z$ budową strategii niskoemisyjnego rozwoju (Low-Emission Development Strategies - LEDS). Choć formalnie nie sformułowano wówczas żadnej definicji LEDS, terminu tego używa się do opisania wychodzących daleko w przyszłość planów/strategii rozwoju, którym będzie towarzyszyć ograniczenie emisji $\mathrm{CO}_{2}$ i innych gazów cieplarnianych.

Zgodnie z definicją podawaną przez Krajową Agencję Poszanowania Energii „gospodarka niskoemisyjna to taka działalność człowieka, która przynosi zysk inwestorom, wzrost gospodarczy krajowi i znaczną redukcję emisji CO ", natomiast w podręczniku dla regionów wydanym przez INTERREG IVC czytamy: „Gospodarka niskoemisyjna to gospodarka, której wzrost osiąga się w wyniku integracji wszystkich aspektów gospodarki wokół niskoemisyjnych technologii i praktyk, wydajnych rozwiązań energetycznych, czystej odnawialnej energii i proekologicznych innowacji technologicznych. W ramach takiej gospodarki w sposób efektywny zużywa się lub wytwarza energię i materiały, a także usuwa bądź odzyskuje odpady metodami minimalizującymi emisję gazów cieplarnianych. Dwutlenek węgla to najważniejszy gaz cieplarniany pod względem ilości, natomiast emisje innych gazów cieplarnianych przelicza się na ekwiwalent dwutlenku węgla ( $\mathrm{CO}_{2}$ eq). Terminologia niskoemisyjna obejmuje zatem całkowitą ilość gazów cieplarnianych" [Budowa..., 2011]. Inaczej mówiąc, w rozwoju gospodarki niskoemisyjnej kładzie się nacisk na zapewnienie korzyści ekonomicznych, społecznych i środowiskowych (zgodnie z zasadami zrównoważonego rozwoju) płynących z działań zmniejszających emisje, osiąganych m.in. poprzez wzrost innowacyjności i wdrażanie nowych technologii, zmniejszenie energochłonności, tworzenie nowych miejsc pracy, a w konsekwencji sprzyjających wzrostowi konkurencyjności gospodarki. Gospodarka niskoemisyjna jest postrzegana w perspektywie długookresowej z uwzględnieniem sprawiedliwości międzygeneracyjnej.

Najważniejsze przesłanki rozwoju gospodarki niskoemisyjnej obejmują zarówno czynniki o charakterze negatywnym, postrzegane jako zagrożenia dla możliwości kontynuacji obecnej koncepcji rozwoju społeczno-gospodarczego, jak i o charakterze pozytywnym, w których upatruje się szans poprawy konkurencyjności i wzrostu efektywności. Do czynników negatywnych zalicza się:

- obserwowane zmiany klimatu pociągające za sobą znaczne zagrożenia dla systemów: przyrodniczego, społecznego i gospodarczego;

- zagrożenia dla zdrowia ludzi związane zwłaszcza z zanieczyszczeniem powietrza, w dużej mierze będącego konsekwencją spalania paliw kopalnych;

- zmiany cykli obiegu substancji w przyrodzie, np. wody i węgla, stwarzające zagrożenia dla wielu ekosystemów, a także systemów społeczno-gospodarczych;

- wyczerpywanie się niektórych surowców kopalnych, zwłaszcza dostępnych w najkorzystniejszych lokalizacjach;

- postępującą degradację środowiska przyrodniczego związaną z eksploatacją zasobów nieodnawialnych, szczególnie surowców energetycznych. 
Czynnikami pozytywnymi są natomiast:

- potencjalne szanse rozwojowe związane z wdrażaniem postępu technicznego w wielu sektorach gospodarki;

- tworzenie nowych miejsc pracy;

- korzystne oddziaływanie na zdrowie ludzi i stan ekosystemów;

- długookresowy potencjał wzrostu konkurencyjności gospodarek poprzez redukcję energochłonności.

Początkowo koncepcja LEDS miała zwiększyć zainteresowanie negocjacjami w sprawie ochrony klimatu krajów rozwijających się jako miękka alternatywa dla dobrowolnych lub obligatoryjnych celów redukcji gazów cieplarnianych. W 2008 roku Unia Europejska wystąpiła z inicjatywą wzmocnienia działań, podkreślając, że informacje o planowanym wejściu na ścieżkę niskoemisyjnego rozwoju pomogą przekonać międzynarodową opinię publiczną odnośnie do potrzeby rozwoju globalnej współpracy na rzecz ochrony klimatu. Odwołania do koncepcji LEDS zostały zawarte w dokumentach końcowych z kolejnych szczytów klimatycznych: w porozumieniu kopenhaskim (2009) i w porozumieniu z Cancún (2010), choć wypada w tym miejscu odnotować, że nie wywarło to większego wpływu na dalszy przebieg negocjacji w sprawie ochrony klimatu.

Ważnym argumentem na rzecz rozwoju gospodarki niskoemisyjnej są również kwestie zdrowotne. Spalanie paliw kopalnych jest źródłem nie tylko emisji gazów cieplarnianych, ale również wielu innych groźnych zanieczyszczeń, które są wprowadzane do powietrza w sposób zorganizowany (poprzez emitory) lub niezorganizowany (z dróg, z hałd lub składowisk, w wyniku pożarów). Światowa Organizacja Zdrowia (WHO) od wielu lat zwraca uwagę na znaczący wpływ jakości powietrza na terenach zamieszkałych na zdrowie i długość życia ludzi [Review of evidence on health aspects of air pollution - REVIHAAP Project, 2013]. Szacuje się, że przeciętna długość życia Europejczyka może być nawet o 9 miesięcy krótsza właśnie z powodu oddychania zanieczyszczonym powietrzem. Naukowo dobrze udokumentowany jest związek pomiędzy zapadalnością na choroby układu oddechowego, nowotwory i inne choroby płuc, choroby układu krążenia i alergie a oddziaływaniem zanieczyszczeń powietrza atmosferycznego w miejscu zamieszkania. Problem jest szczególnie znaczący na obszarach silnie zurbanizowanych o dużym nasileniu transportu.

Przy ocenie jakości powietrza pod uwagę brane są zanieczyszczenia pyłowe i gazowe. W przypadku pyłów badany jest wpływ PM10 i PM2,5 (PM - Particulate Matter). PM10 to pyły o średnicy aerodynamicznej mniejszej niż $10 \mu \mathrm{m}$, które mogą docierać do górnych dróg oddechowych i płuc. PM2,5 to cząstki pyłu o średnicy aerodynamicznej mniejszej niż $2,5 \mu \mathrm{m}$, które nie tylko przedostają się do układu oddechowego, ale mają zdolność przenikania przez ściany naczyń krwionośnych. Pył jest zanieczyszczeniem składającym się z mieszaniny substancji organicznych i nieorganicznych zawieszonych w powietrzu w postaci cząstek stałych i/lub ciekłych. Może zawierać substancje toksyczne, takie jak wielopierścieniowe węglowodory aromatyczne (m.in. benzo(a)piren B(a)P), metale ciężkie oraz dioksyny i furany). Cząstki te różnią się wielkością, składem i pochodzeniem. Wysokiej toksyczności niektórych substancji towarzyszy zdolność do kumulacji w organizmie. Wiele z nich jest silnie rakotwórczych i mutagennych (zob. rozdział Miasto jako system ekologiczny).

Do głównych zanieczyszczeń gazowych powstających w wyniku spalania paliw kopalnych należą: dwutlenek węgla, tlenek węgla, dwutlenek siarki, tlenki azotu. Są to gazy o różnym czasie trwania w atmosferze, reaktywności i sile negatywnego oddziaływania na ludzi i środowisko (Kociołek-Balawejder, Stanisławska, 2012, s. 106-137). 


\subsection{Gospodarka niskoemisyjna w regulacjach prawnych i polityce Unii Europejskiej}

\subsubsection{Pakiet klimatyczno-energetyczny}

Wyraźnym sygnałem świadczącym o intensyfikacji działań na rzecz ochrony klimatu i gospodarki niskoemisyjnej w UE był pakiet klimatyczno-energetyczny zaproponowany przez Komisję Europejską 10 stycznia 2007 roku. Propozycja KE została zaaprobowana przez Parlament Europejski i przywódców krajów członkowskich UE w marcu tego samego roku. Cele pakietu stały się znane pod skróconą nazwą $3 \times 20$, co oznaczało:

- zmniejszenie emisji gazów cieplarnianych przynajmniej o $20 \%$ do 2020 roku w porównaniu do roku bazowego 1990 lub o $30 \%$ w przypadku, gdyby uzyskano światowe porozumienie co do redukcji gazów cieplarnianych;

- zwiększenie udziału energii ze źródeł odnawialnych w zużyciu energii końcowej do $20 \%$ do 2020 roku, w tym $10 \%$ udziału biopaliw w zużyciu paliw w transporcie;

- zwiększenie efektywności wykorzystania energii o 20\% do 2020 roku w porównaniu do prognozy zapotrzebowania na paliwa i energię.

Najważniejsze przepisy prawne związane z realizacją celów pakietu klimatyczno-energetycznego zostały zawarte w trzech dyrektywach przyjętych 23 kwietnia 2009 roku:

- znowelizowanej dyrektywie o europejskim systemie handlu uprawnieniami do emisji EU ETS [2008/16];

- dyrektywie w sprawie promowania stosowania energii ze źródeł odnawialnych [2008/19];

- dyrektywie w sprawie geologicznego składowania dwutlenku węgla, zwanej dyrektywą CCS [2008/31].

Wkrótce pojawiły się kolejne przepisy, które dotyczą głównie kwestii efektywności energetycznej. Najważniejsze z nich to :

- dyrektywa ustanawiająca ogólne zasady ustalania wymogów dotyczących ekoprojektu dla produktów związanych z energią [2009/125/WE];

- dyrektywa w sprawie charakterystyki energetycznej budynków [2010/31/ UE];

- dyrektywa w sprawie efektywności energetycznej [2012/27/UE].

Przyjęcie dyrektyw jest efektem wieloletnich działań KE nie tylko na rzecz ochrony klimatu, ale również poprawy efektywności energetycznej gospodarki Wspólnoty. Poprawa efektywności energetycznej nazywana jest nawet „szóstym paliwem", gdyż kryje w sobie znaczny potencjał, możliwy do wykorzystania zamiast budowy kolejnych bloków energetycznych. Działania na rzecz gospodarki niskoemisyjnej są synergicznie powiązane ze zmniejszaniem zależności UE od importu paliw kopalnych, budowaniem konkurencyjności europejskiego przemysłu motoryzacyjnego, ochroną zdrowia (zwłaszcza w kontekście poprawy jakości powietrza). Dlatego z działaniami na rzecz gospodarki niskoemisyjnej ściśle powiązana jest też dyrektywa CAFE w sprawie jakości powietrza i czystszego powietrza dla Europy 2008/50/WE.

Działania w kierunku rozwoju gospodarki niskoemisyjnej znajdują swoje odzwierciedlenie w licznych dokumentach i planach przyjmowanych na szczeblu Wspólnoty. Przykładowo są to: Plan działania na rzecz racjonalizacji zużycia energii: sposoby wykorzystania potencjału [COM(2006)0545], Europa 2020 Strategia na rzecz inteligentnego, trwałego i sprzyjającego włączeniu społecznemu wzrostu gospodarcze- 
go; Plan na rzecz efektywności energetycznej z 2011 roku (EEP) [COM(2011)0109] i Biała księga w sprawie transportu [2011]. Świadczą one o determinacji w dążeniu do osiągnięcia celów redukcji emisji zanieczyszczeń powietrza w powiązaniu z bardzo ambitnymi celami rozwojowymi, wzrostem konkurencyjności i tworzeniem nowych miejsc pracy dzięki nowym inwestycjom w sektorze publicznym i prywatnym. (W 2014 r. Rada Europejska zatwierdziła wiążący UE cel ograniczenia wewnętrznych emisji gazów cieplarnianych do 2030 r. o co najmniej $40 \%$ w porównaniu z poziomem z 1990 r. Do 2050 r. zmniejszenie emisji dwutlenku węgla ma osiągnąć 8590\%). Wśród pięciu celów zaproponowanych przez KE do realizacji do 2020 roku są zmiany klimatu i energia (pozostałe cele to zatrudnienie, badania i innowacje, edukacja oraz walka z ubóstwem) [Europa 2020, 2010]. W 2030 roku udział energii ze źródeł odnawialnych w energii zużywanej w UE ma wynosić co najmniej 27\% i także $27 \%$ wynosi orientacyjny cel dotyczący poprawy efektywności energetycznej w 2030 roku w porównaniu z prognozami zużycia energii w przyszłości w oparciu o obecne kryteria [EUCO 169/14COEUR 13CONCL 5].

Spektrum planowanych działań jest bardzo szerokie i właściwie obejmuje wszystkie sektory gospodarki. W dalszych rozważaniach zajmiemy się wyłącznie zagadnieniami możliwymi do realizacji na terenach miejskich. Są to: zaopatrzenie w energię, budownictwo ( $w$ tym mieszkalnictwo i usługi), transport i odnawialne źródła energii.

\subsubsection{Gospodarka niskoemisyjna w polityce spójności}

W latach 2007-2013 z Europejskiego Funduszu Rozwoju Regionalnego (EFRR) i z Funduszu Spójności zainwestowano 18,5 mld EUR w działania związane z gospodarką niskoemisyjną, takie jak odnawialne źródła energii, efektywność energetyczna, czysty transport miejski oraz ścieżki rowerowe.

W latach 2014-2020 planuje się wzmocnienie tych działań. Wspieranie przejścia na gospodarkę niskoemisyjną jest jednym z czterech kluczowych obszarów, na które państwa członkowskie i regiony muszą ukierunkować swoje inwestycje w celu realizacji aktualnie obowiązującej polityki spójności (pozostałe trzy to: badania i innowacje, technologie informacyjno-komunikacyjne i wspieranie konkurencyjności MŚP). Jeden z jedenastu priorytetów polityki spójności na lata 2014-2020 (czyli tzw. celów tematycznych), a dokładnie cel 6 zatytułowano Wspieranie przejścia na gospodarkę niskoemisyjna we wszystkich sektorach. Sformułowanie tego priorytetu daje szerokie możliwości działania na rzecz ograniczenia emisji pochodzących z budownictwa, ciepłownictwa oraz transportu. Jak napisano w Umowie Partnerstwa, w ramach tego priorytetu wsparciem będą objęte, po pierwsze, budynki mieszkalne wielorodzinne (m.in. budynki czynszowe, komunalne, które charakteryzują się wysoką, prawie 70\% tzw. luką remontową) oraz budynki użyteczności publicznej (m.in. objęte obowiązkiem termomodernizacji na podstawie art. 5 ust. 1 dyrektywy 2012/27/UE w sprawie efektywności energetycznej). Po drugie, w zakresie oddziaływania priorytetu znajdują się również inwestycje w obszarze transportu miejskiego. Finansowaniem mają być objęte infrastruktura transportu publicznego, tabor (w tym infrastruktura do jego obsługi, np. instalacje do dystrybucji nośników energii), węzły przesiadkowe, w tym parkingi oraz tzw. inteligentne systemy transportowe, mające na celu przede wszystkim poprawę warunków transportu publicznego bądź niezmotoryzowanego.

W polityce spójności na lata 2014-2020 określono minimalny poziom środków uzyskanych z Europejskiego Funduszu Rozwoju Regionalnego (EFRR), które każdy z regionów będzie musiał zainwestować na wsparcie przejścia na gospodarkę niskoemisyjną. Określono następujące udziały procentowe: 
- 20\% w regionach bardziej rozwiniętych;

- $15 \%$ w regionach w okresie przejściowym;

- $12 \%$ w regionach mniej rozwiniętych.

Zapewni to w latach 2014-2020 inwestycje z EFRR na poziomie co najmniej 23 mld euro, które będą uzupełniane inwestycjami finansowanymi z Funduszu Spójności. Inwestycje finansowane z obu tych funduszy mają być realizowane w następujących obszarach:

- zwiększenie wykorzystania odnawialnych źródeł energii (inwestowanie w produkcję i dystrybucję energii uzyskiwanej ze źródeł odnawialnych; wspieranie projektów mających na celu upowszechnianie wiedzy o odnawialnych źródłach energii oraz zwiększenie ich wykorzystania w sektorze zarówno publicznym, jak i prywatnym);

- zmniejszenie zużycia energii (projekty mające na celu zwiększenie efektywności energetycznej oraz inteligentne zarządzanie energią w infrastrukturze publicznej, w tym w budynkach publicznych, w sektorze mieszkalnictwa oraz w produkcji przemysłowej z myślą o zwiększeniu konkurencyjności, zwłaszcza w sektorze MŚP);

- zmniejszenie emisji związanej z transportem (wspieranie rozwoju nowych technologii i promowanie różnych zrównoważonych form mobilności w miastach, w tym transportu publicznego oraz przemieszczania się na rowerze i pieszo);

- promowanie inteligentnych systemów energetycznych (inwestowanie w inteligentne sieci dystrybucji energii, aby umożliwić zwiększenie efektywności energetycznej; integracja większych ilości energii ze źródeł odnawialnych);

- zachęcanie do zintegrowanego podejścia do kształtowania i wdrażania polityki (opracowywanie zintegrowanych niskoemisyjnych strategii gospodarczych, w szczególności dla obszarów miejskich, które mogą obejmować oświetlenie uliczne, różne zrównoważone formy mobilności w miastach oraz inteligentne sieci energetyczne; promowanie badań i innowacji w dziedzinie technologii niskoemisyjnych).

Środki z Europejskiego Funduszu Społecznego będzie można wykorzystać na wzmocnienie systemów kształcenia i szkoleń niezbędnych do zdobycia przez pracowników umiejętności i kwalifikacji potrzebnych do pracy w sektorach związanych z energią i środowiskiem.

Należy podkreślić, że środki z polityki spójności stanowią podstawę realizacji celów strategii Europa 2020, w tym celów dotyczących odnawialnych źródeł energii oraz efektywności energetycznej. Państwa członkowskie muszą opracować krajowe plany działań w zakresie energii ze źródeł odnawialnych z priorytetami w zakresie zwiększenia udziału takich źródeł, a także krajowe plany działań na rzecz racjonalizacji użytkowania energii. Opracowanie takich planów jest warunkiem otrzymania wsparcia.

Równolegle prowadzone są działania na rzecz efektywności energetycznej produktów. Z punktu widzenia rozwoju gospodarki niskoemisyjnej na terenach zurbanizowanych może się to okazać istotne przynajmniej z trzech powodów. Po pierwsze, tworzy to możliwość stosowania odpowiednich kryteriów co do przedmiotu zamówienia w przetargach publicznych. Po drugie, dostępność takich bardziej efektywnych energetycznie produktów może wpływać na zachowania konsumentów zainteresowanych nie tylko kwestiami ochrony środowiska, ale również oszczędniejszym wydatkowaniem środków np. na eksploatację sprzętu AGD czy transport. Po trzecie, popyt na bardziej efektywne energetycznie produkty będzie stymulować wzrost ich podaży przez producentów, którzy dodatkowo mogą liczyć na środki na $B+R$ w celu 
rozwoju nowych technologii. Wciąż wiele produktów ma znaczny potencjał związany z różnymi możliwościami poprawy ich efektywności energetycznej i redukcji wpływu na środowisko. Są to liczne produkty stosowane w budownictwie (np. okna i materiały izolacyjne), w gospodarstwach domowych (np. sprzęt AGD), w transporcie, zwłaszcza publicznym.

Z zaprezentowanego przeglądu dokumentów UE jasno wynika, że rozwój gospodarki niskoemisyjnej stał się jednym z kluczowych obszarów zainteresowania Wspólnoty, która wiąże z nim dalekosiężne nadzieje na wzrost dobrobytu obywateli i konkurencyjności gospodarki na arenie międzynarodowej. Państwom członkowskim pozostawiono możliwość pewnej indywidualizacji działań zgodnie z lokalną specyfiką, wyboru najbardziej adekwatnych narzędzi wdrażania regulacji i wsparcia adresowanego głównie do sektora prywatnego, a także wytyczania jeszcze bardziej ambitnych celów. Warto nadmienić, że inne wiodące pozaeuropejskie gospodarki również uruchomiły działania zbieżne z ideą gospodarki niskoemisyjnej, zwłaszcza w zakresie transportu i OZE.

\subsection{Gospodarka niskoemisyjna w Polsce}

Rozwój gospodarki niskoemisyjnej w Polsce nie natrafił niestety na podatny grunt z powodu zdecydowanego oporu ze strony bardzo silnego lobby energetyczno-węglowego i braku gotowości głównych sił politycznych kraju do podjęcia działań o charakterze strategicznym (o perspektywie minimum do 2030, a najlepiej do 2050 r.) dla rozwoju przyjaznego ludziom i środowisku sektora energetycznego. Pomimo rosnącego zainteresowania obywateli poprawą jakości powietrza (zwłaszcza w miastach) i rozwojem prosumenckiej produkcji energii wdrażanie niektórych regulacji i bardziej ambitnych planów wciąż przebiega z pewnymi opóźnieniami w stosunku do wytycznych UE. Ilustracją tego są wieloletnie zmagania związane z transpozycją do prawa krajowego dyrektywy o OZE - zakończone przyjęciem w lutym 2015 roku zamiast w grudniu 2010 roku odpowiedniej ustawy. Kolejny przykład stanowi ustawa o efektywności energetycznej. Obecna przestanie obowiązywać z końcem 2016 roku, a główny mechanizm wspierania oszczędzania energii, czyli system „białych certyfikatów", będzie działał tylko do marca 2016 roku. Opieszałość legislacyjna będzie skutkowała niespełnieniem krajowego celu efektywności energetycznej do 2020 roku, likwidacją systemu wsparcia w tej dziedzinie, a także dalszym opóźnieniem w transpozycji dyrektywy 2012/27/UE. Biorąc pod uwagę, że nadal zużywamy więcej energii w przeliczeniu na jednostkę PKB niż wynosi średnia europejska, brak nowej ustawy można interpretować jako aprobatę dalszego marnotrawstwa energii i większych emisji $\mathrm{CO}_{2}$. Pozostaje to w sprzeczności z realizacją polityki klimatycznej, a także generuje społeczne, gospodarcze i środowiskowe koszty.

Jednocześnie warto podkreślić, że powstają wartościowe opracowania na temat możliwości wdrażania gospodarki niskoemisyjnej w Polsce, ale pochodzą one ze źródeł pozarządowych. Przykładami są Niskoemisyjna strategia dla Polski do roku 2050 autorstwa M. Bukowskiego z Warszawskiego Instytutu Studiów Ekonomicznych i A. Kassenberga z Instytutu na rzecz Ekorozwoju oraz Transformacja w kierunku gospodarki niskoemisyjnej w Polsce Banku Światowego [2011].

W opracowanych przez Ministerstwo Gospodarki Założeniach do Narodowego Planu Rozwoju Gospodarki Niskoemisyjnej brak jest nawet typowej definicji tego typu gospodarki. Podkreślono natomiast, że: „przestawienie gospodarki na gospodarkę niskoemisyjną, a tym samym ograniczenie emisji gazów cieplarnianych i innych substancji uważa się nie tylko za kluczowy krok w kierunku zapewnienia stabilnego środowiska, lecz także element długofalowego zrównoważonego rozwoju" [ZNPR- 
GN, 2011, s. 6]. Istotą programu jest zapewnienie korzyści ekonomicznych, społecznych i środowiskowych (zgodnie z zasadą zrównoważonego rozwoju) płynących z działań zmniejszających emisje, osiąganych m.in. poprzez wzrost innowacyjności i wdrożenie nowych technologii, zmniejszenie energochłonności, tworzenie nowych miejsc pracy, a w konsekwencji sprzyjających wzrostowi konkurencyjności gospodarki. W praktyce oznacza to koncentrację na celu głównym: rozwoju gospodarki niskoemisyjnej przy zapewnieniu zrównoważonego rozwoju kraju i sześciu celach szczegółowych:

1) rozwoju niskoemisyjnych źródeł energii;

2) poprawie efektywności energetycznej;

3) poprawie efektywności gospodarowania surowcami i materiałami;

4) rozwoju i wykorzystaniu technologii niskoemisyjnych;

5) zapobieganiu powstawaniu oraz poprawie efektywności gospodarowania odpadami;

6) promocji nowych wzorców konsumpcji.

Do tych poprawnie wytyczonych celów należałoby jeszcze dopisać odpowiednie programy realizacji i instrumenty wdrażania. Pozostaje to słabą stroną polskiego systemu legislacyjnego. Działania są generalnie wymuszone wymaganiami UE, a i w tym zakresie zdarzają się opóźnienia i zaniechania. Dowodem na to może być druzgocący w swej wymowie raport NIK z października 2014 roku Ochrona powietrza przed zanieczyszczeniami, z którego jasno wynika, że „organy władzy publicznej działają nieskutecznie w sferze ochrony powietrza, nie zapewniając dostatecznej ochrony ludzi i środowiska naturalnego przed negatywnymi skutkami jego zanieczyszczenia. W kontrolowanym okresie w dalszym ciągu nie były dotrzymywane normy jakości powietrza, przyjęte w ustawodawstwie Unii Europejskiej, a implementowane do krajowego porządku prawnego. Świadczą o tym pomiary wykonywane przez inspekcję ochrony środowiska oraz sporządzane na ich podstawie okresowe oceny jakości powietrza. Wskazują one, że największy problem dla jakości powietrza w skali kraju stanowiły ponadnormatywne stężenia pyłu PM10 oraz benzo(a)pirenu, których głównym źródłem była tzw. niska emisja" [Raport NIK, 2014, s. 10].

Niska emisja jest to emisja pyłów i szkodliwych gazów pochodząca z palenisk domowych i lokalnych kotłowni węglowych, w których spalanie węgla odbywa się w sposób nieefektywny. Niekorzystne oddziaływanie jest dodatkowo wzmacniane przez nagminne spalanie tam śmieci, co prowadzi do uwalniania do powietrza wielu toksycznych i kancerogennych związków. Cechą charakterystyczną niskiej emisji jest to, że jest powodowana przez bardzo liczne źródła emitujące do powietrza niewielkie ilości zanieczyszczeń. Ze względu na dużą liczbę emitorów sumaryczny efekt jest znaczny. Ponieważ zanieczyszczenia są wyprowadzane z kominów o niewielkiej wysokości, powoduje to, że zjawisko to jest bardzo uciążliwe, gdyż zanieczyszczenia gromadzą się blisko powierzchni ziemi wokół miejsca powstawania. Są to najczęściej obszary o zwartej zabudowie mieszkaniowej. Niska emisja stanowi problem ogólnokrajowy, ale jest szczególnie dokuczliwa na terenach zurbanizowanych. Należy podkreślić, że wdrażanie gospodarki niskoemisyjnej jest zbieżne ze skuteczną walką z niskimi emisjami. Dlatego warto te cele traktować łącznie i dostrzegać związane z nimi korzyści zdrowotne i ekonomiczne.

Dokumentem o charakterze strategicznym jest Krajowy program ochrony powietrza KPOP, w którym wyznacza się cele i kierunki działań, jakie powinny zostać uwzględnione w poszczególnych programach ochrony powietrza (POP), obowiązkowo opracowywanych przez samorządy wojewódzkie zgodnie z art. 91 Prawa ochrony środowiska. Zgodnie z przepisami o ochronie środowiska uprawnienie do opracowania KPOP przysługuje Ministrowi Środowiska, w przypadku gdy przekroczenie 
poziomów dopuszczalnych lub docelowych substancji w powietrzu występuje na znacznym obszarze kraju, a środki podjęte przez organy samorządu terytorialnego nie wpływają na ograniczenie emisji zanieczyszczeń do powietrza. Celem POP jest osiągnięcie poziomów normatywnych substancji w powietrzu.

Na poziomie gminnym opracowuje się programy ograniczania niskiej emisji PONE. Ich celem jest ograniczenie emisji zanieczyszczeń do powietrza ze źródeł powierzchniowych. Opracowanie PONE nie jest obowiązkowe, ale jest pomocne w przypadku ubiegania się o dotacje ze środków publicznych na rozwój gospodarki niskoemisyjnej.

W Polsce na podstawie ustawy o wspieraniu przedsięwzięć termomodernizacyjnych od 1999 roku realizowany jest program termomodernizacji budynków. Program ten ma na celu zapewnienie technicznego i finansowego wsparcia projektów w zakresie oszczędności energii w budynkach oraz projektów dotyczących zmniejszania strat ciepła w sieciach dystrybucyjnych lub zastępowania tradycyjnych źródeł energii źródłami niekonwencjonalnymi, w tym odnawialnymi. Zebrane doświadczenia warto wesprzeć bardziej ambitnymi celami, zgodnie $z$ aktualnymi wytycznymi UE, i realizować projekty głębokiej termomodernizacji.

W programach regionalnych przewidziano różne mechanizmy realizacji projektów z zakresu gospodarki niskoemisyjnej: mechanizm horyzontalny, czyli finansowanie indywidualnego projektu samorządu lub przedsiębiorcy w ramach danej osi i priorytetu inwestycyjnego, lub mechanizm zintegrowany - projekty w ramach pakietu przewidzianego strategią ZIT, a także instrumenty dla regionalnych i subregionalnych mechanizmów zintegrowanych.

Bardzo ważne jest, by władze miast, które chcą realizować projekty z zakresu gospodarki niskoemisyjnej, pamiętały, że niezbędny do tego jest plan gospodarki niskoemisyjnej. Wszystkie projekty z zakresu gospodarki niskoemisyjnej muszą być $w$ tych planach ujęte. Jest to obowiązek gmin. Powiaty takiego obowiązku nie mają. Jednak z punktu widzenia interesu całej lokalnej społeczności i rozwoju całego obszaru warto, by administracje gmin i powiatu porozumiały się co do umieszczenia przedsięwzięć powiatowych w planach gminnych. Trzeba dodać, że Narodowy Fundusz Ochrony Środowiska i Gospodarki Wodnej oferuje wsparcie dla gmin w przygotowaniu planów gospodarki niskoemisyjnej.

\section{4. Ślad węglowy miasta}

Ślad węglowy (Carbon Footprint - CF) to ilość gazów cieplarnianych wyemitowanych w związku z bezpośrednią, jak i pośrednią działalnością człowieka, zwykle wyrażana w tonach lub kilogramach dwutlenku węgla. Jest rodzajem śladu ekologicznego, którego idea jako sposobu pomiaru antropopresji po raz pierwszy pojawiła się w połowie lat 90. XX wieku. Ślad węglowy możemy określać w odniesieniu do osób, produktów, usług, sklepów, imprez masowych, przedsiębiorstw, miast, a nawet całych państw. Jego obliczanie obejmuje emisję wszystkich gazów cieplarnianych. Przypomnijmy, że zgodnie z Protokołem z Kioto oprócz dwutlenku węgla są to metan, podtlenek azotu, fluoropochodne węglowodorów, perfluoropochodne związki węgla, sześciofluorek siarki. Miarą śladu węglowego jest $\mathrm{tCO}_{2} \mathrm{e}-\mathrm{tzw}$. tona ekwiwalentu dwutlenku węgla. Sprawą kluczową dla prawidłowego rozwoju gospodarki niskoemisyjnej jest właściwy pomiar i ewidencjonowanie emisji.

Rozwój gospodarki niskoemisyjnej jest zorientowany na redukcję całkowitej emisji gazów cieplarnianych, która ewidencjonowana jest po jej przeliczeniu na dwutlenek węgla, dla którego przyjęto współczynnik globalnego ocieplenia równy jeden. 
Współczynnik globalnego ocieplenia (GWP) obliczany jest na podstawie skutków oddziaływania jednego kilograma danego gazu na ocieplenie klimatu w ciągu 100 lat w porównaniu do oddziaływania jednego kilograma $\mathrm{CO}_{2}$. Aby obliczyć wpływ emisji określonego gazu, należy znać jej wielkość (zmianę stężenia danego gazu cieplarnianego w atmosferze) oraz wynikającą z tego zmianę natężenia promieniowania podczerwonego. Wartość GWP pokazuje zatem, o ile wyemitowanie $1 \mathrm{~kg}$ dowolnego gazu cieplarnianego jest bardziej lub mniej szkodliwe (w mniejszym lub większym stopniu zmienia natężenie promieniowania podczerwonego) od wyemitowania $1 \mathrm{~kg}$ dwutlenku węgla. Jeśli więc GWP dla metanu $\left(\mathrm{CH}_{4}\right)$ wynosi $25 \mathrm{kgeqCO} / \mathrm{kg}$, to oznacza, że wyemitowanie $1 \mathrm{~kg}$ metanu powoduje taki efekt w zakresie globalnego ocieplenia, jak wyemitowanie 25 kg dwutlenku węgla. Przykładowe dane na ten temat wraz z podaniem czasu trwania w atmosferze zawiera tabela 8.1. Możliwość przeliczania emisji różnych gazów na tę samą jednostkę umożliwia ich dodawanie i uzyskanie w konsekwencji jednej liczby, określanej jako wartość śladu węglowego (CF). Wartość ta powstaje poprzez określenie emisji i usunięć gazów cieplarnianych w mieście np. w ciągu roku i przemnożenie ich przez odpowiadające im wartości GWP, a następnie zsumowanie. Wynik jest wyrażony w jednostce masowej (kilogramach, tonach) jako ekwiwalent $\mathrm{CO}_{2}$.

Tabela 8.1. Współczynniki globalnego ocieplenia według nomenklatury zalecanej przez IPCC

\begin{tabular}{|c|c|c|}
\hline Nazwa gazu & $\begin{array}{l}\text { Czas trwania w atmosferze } \\
\text { w latach }\end{array}$ & $\begin{array}{l}\text { Współczynnik globalnego } \\
\text { ocieplenia }\end{array}$ \\
\hline Dwutlenek węgla $\left(\mathrm{CO}_{2}\right)$ & 7 & 1 \\
\hline $\operatorname{Metan}\left(\mathrm{CH}_{4}\right)$ & 12 & 25 \\
\hline Podtlenek azotu $\left(\mathrm{N}_{2} \mathrm{O}\right)$ & 114 & 298 \\
\hline $\begin{array}{l}\text { Substancje kontrolowane } \\
\text { przez Protokół montrealski }\end{array}$ & $\begin{array}{l}\text { od 0,7 (bromek metylu) do } 1700 \\
\text { (CFC-115) }\end{array}$ & $\begin{array}{l}\text { od } 5 \text { (bromek metylu) do } 14400 \\
\text { (CFC-13) }\end{array}$ \\
\hline Hydrofluorokarbony & $\begin{array}{l}\text { od } 1,4 \text { (HFC-152a) do } 270 \text { (HFC- } \\
23)\end{array}$ & $\begin{array}{l}\text { od } 124 \text { (HFC-152a) do } 14800 \\
\text { (HFC-23) }\end{array}$ \\
\hline Związki perfluorowane & $\begin{array}{l}\text { od } 740 \text { (trójfluorek azotu } \mathrm{NF}_{3} \text { ) } \\
\text { do } 50000 \text { (czterofluorek węgla } \\
\left(\mathrm{CF}_{4}\right) \text { ) }\end{array}$ & $\begin{array}{l}\text { od } 7390 \text { (czterofluorek węgla } \\
\left.\left(\mathrm{CF}_{4}\right)\right) \text { do } 22800 \text { (sześciofluorek } \\
\text { siarki }\left(\mathrm{SF}_{6}\right) \text { ) }\end{array}$ \\
\hline
\end{tabular}

Źródto: opracowanie wtasne na podstawie raportów IPCC, https://www.ipcc.ch/publications_and_data/ar4/wg1/en/ ch2s2-10-2.html.

Przystępując do pomiarów emisji wyjściowych i śledzenia ich zmian, należy zdecydować się na postępowanie według określonej procedury. Warte uwagi są dwie: pierwsza polega na obliczaniu śladu węglowego produktu (Carbon Footprint of a Product - CFP) zgodnie ze standardami wyznaczonymi przez IPCC (Intergovernmental Panel on Climate Change), druga oparta jest na cyklu życia produktu (Life Cycle Assessment - LCA).

Porównując te metody, można stwierdzić, że obie zostały znormalizowane i istnieją normy ISO obejmujące wytyczne do ich wykonywania i stosowania (LCA 
dotyczy grupa norm ISO 14040x (14040, 14044, 14048, 14049), CFP - norma ISO 14067:2013 Greenhouse gases - Carbon footprint of products - Requirements and guidelines for quantification and Communications). Specyfika problemu emisyjności obszarów zurbanizowanych wymaga starannego przemyślenia wyboru metody, gdyż normy te nie zostały wprost dedykowane do miejskich zastosowań. Obie metody pozwalają na uzyskanie ilościowych wyników wyrażonych liczbą zaopatrzoną w odpowiednią jednostkę i dotyczą całej emisji gazów cieplarnianych. Zasadnicza różnica pomiędzy tymi metodami polega na tym, że ślad węglowy dotyczy tylko jednego problemu środowiskowego, jakim jest globalne ocieplenie, LCA zaś pokazuje oddziaływanie wyrobów na środowisko w szerszym kontekście. Z metodycznego punktu widzenia CFP stanowi fragment badań LCA. W praktyce analizy LCA obejmują kilkanaście problemów środowiskowych, wśród których zawsze jest globalne ocieplenie (zmiany klimatyczne). Można oczywiście ograniczyć się wyłącznie do analizy emisji gazów cieplarnianych związanych ze stosowaniem paliw kopalnych, ale w odniesieniu do całego cyklu ich życia, to znaczy od wydobycia poprzez transport aż do ich energetycznego wykorzystania i usunięcia pozostałości (np. popiołów). Oznacza to konieczność śledzenia emisji bezpośrednich ze spalania paliw w budynkach, instalacjach i transporcie oraz emisji pośrednich towarzyszących produkcji energii elektrycznej, ciepła i chłodu wykorzystywanych przez mieszkańców, a powstających również poza granicami administracyjnymi miasta.

Wykorzystywane w metodzie CF standardowe wskaźniki emisji opierają się na zawartości węgla w poszczególnych paliwach i są stosowane do inwentaryzacji gazów cieplarnianych przez strony Ramowej konwencji Narodów Zjednoczonych w sprawie zmian klimatu. Jest to niewątpliwa zaleta tej metody, gdyż Polska ma już doświadczenie w jej stosowaniu, po pierwsze, jako strona konwencji klimatycznej, po drugie, prowadząc ewidencje na potrzeby monitorowania postępów w realizacji celów pakietu klimatyczno-energetycznego UE. Ewidencjonuje się $\mathrm{CO}_{2}$, opcjonalnie zaś $\mathrm{CH}_{4} \mathrm{i} \mathrm{N}_{2} \mathrm{O}$ (można je pominąć). Emisje $\mathrm{CO}_{2}$ powstające w wyniku spalania biomasy, biogazu i biopaliw wytwarzanych w zrównoważony sposób oraz emisje związane z wykorzystaniem certyfikowanej zielonej energii elektrycznej traktowane są jako zerowe. IPCC co jakiś czas publikuje wytyczne, w których podaje aktualne wartości wskaźników.

W metodzie LCA, ze względu na konieczność wzięcia pod uwagę również emisji powstałych poza granicami obszaru, na którym wykorzystywane są paliwa, emisje powstające $w$ wyniku spalania biomasy, biogazu i biopaliw traktowane są jako wyższe od zera. Za zasadne uważa się także uwzględnianie emisji innych gazów cieplarnianych. Metodologia ta, wykorzystywana do wyznaczania śladu węglowego, obejmuje zatem szersze spektrum oddziaływań niż emisje $\mathrm{CO}_{2}$ powstałe na terenie miasta. Stanowiła podstawę przy opracowywaniu strategii tematycznej w sprawie zrównoważonego wykorzystania zasobów naturalnych oraz zapobiegania powstawaniu odpadów i ich recyklingu [COM(2005)666 końcowy], Dyrektywy w sprawie ekoprojektowania [2009/125/WE] i Rozporządzenia w sprawie oznakowania ekologicznego.

Obie wymienione metody zostały już dobrze opisane w literaturze przedmiotu i istnieją opracowane dla nich narzędzia umożliwiające sporządzanie inwentaryzacji dla całego miasta lub aglomeracji. Do władz samorządowych należy decyzja, czy przedmiotem ewidencji będzie emisja $\mathrm{CO}_{2}, \mathrm{Czy} \mathrm{CO}_{2}$ eq. Wybór metody powinien być dokładnie przemyślany, dostosowany do lokalnej specyfiki i możliwości organizacyjnych. Jest to bardzo ważne, gdyż tylko prawidłowo przeprowadzona ewidencja emisji może stanowić podstawę budowania strategii gospodarki niskoemisyjnej na danym terenie. Warto zwrócić uwagę np. na takie kwestie, jak: 
- wielkość emisji $\mathrm{CO}_{2}$ w związku z zasilaniem w energię elektryczną i ciepło użytkowników końcowych na terenie miasta;

- produkcja ciepła/chłodu jako towaru dostarczanego użytkownikom końcowym na terenie miasta;

- istotność emisji $\mathrm{CH}_{4}$ i $\mathrm{N}_{2} \mathrm{O}$ związanych z funkcjonowaniem miejskich składowisk odpadów, oczyszczalni ścieków, transportu;

- wykorzystywanie paliw i ciepła pochodzących ze źródeł odnawialnych;

- pochodzenie energii elektrycznej (z sieci krajowej lub z produkcji lokalnej);

- zakup certyfikowanej zielonej energii przez samorząd lokalny;

- kogeneracja, czyli łączna produkcja energii elektrycznej i cieplnej wykorzystywanej na ternie miasta.

Wymienione kategorie zagadnień problemowych świadczą o złożoności procesu ewidencjonowania emisji gazów cieplarnianych na terenie poszczególnych jednostek terytorialnych. Choć formalnie można ograniczyć działania do obiektów będących pod bezpośrednim zarządem władz miasta, to jednak szersze spojrzenie na problem emisji może przynieść zaskakująco dobre efekty w postaci poprawy jakości powietrza, zwłaszcza na terenach zurbanizowanych o zwartej zabudowie, gdzie w sezonie grzewczym poważnym zagrożeniem jest smog.

Samorządy lokalne zainteresowane prowadzeniem zrównoważonej gospodarki energetycznej i działaniami na rzecz redukcji emisji $\mathrm{CO}_{2}$ mogą wzorować się na Porozumieniu Burmistrzów i procedurze SEAP. Mogą również wykorzystywać inne opracowania, jak np. Międzynarodowy Protokół Analizy Gazów Cieplarnianych z Obszarów Miasta/Gminy (IEAP), który zawiera wskaźniki emisji specyficzne dla poszczególnych krajów.

\section{Porozumienie Burmistrzów dla zrównoważonej gospodarki energetycznej}

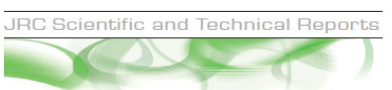

PORADNIK

Jak opracować plan działań na rzecz zrównoważonej energii [SEAP]?
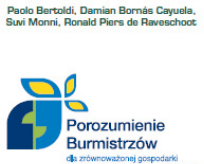

JRC ie

Dobrym przykładem opisu procedur związanych z rozwojem gospodarki niskoemisyjnej jest poradnik Jak opracować plan działań na rzecz zrównoważonej energii (SEAP)? opracowany na potrzeby Porozumienia Burmistrzów dla zrównoważonej gospodarki energetycznej na szczeblu lokalnym przez Instytut ds. Energii Wspólnego Centrum Badawczego.

Porozumienie Burmistrzów jest europejską inicjatywą, w ramach której miasta, miejscowości i regiony dobrowolnie zobowiązują się do ograniczenia na swoim terenie emisji $\mathrm{CO}_{2}$ o co najmniej $20 \%$ do 2020 r. Wywiązanie się z tego oficjalnego zobowiązania wymaga opracowania przez każde z nich Planu działań na rzecz zrównoważonej energii (SEAP). Celem poradnika jest pomoc sygnatariuszom Porozumienia Burmistrzów w realizacji zobowiązań podjętych poprzez podpisanie porozumienia. Plany mają dostarczyć informacji na temat źródeł emisji $\mathrm{CO}_{2}$ występujących na terenie miasta (gminy) i pomóc w ten sposób w doborze odpowiednich działań prowadzących do redukcji emisji.

Źródto: http:/ / wnw.covenantofmayors.eu/IMG/ pdf/SEAP_guidebook_PL_final.pdf [dostęp 12.07.20157.
Źródto: opracowanie wlasne na podstawie Jak opracować plan działań na rzecz zrównoważonej energii (SEAP)? 
Zgodnie z procedurą SEAP punktem wyjścia do budowy gospodarki niskoemisyjnej jest sporządzenie bazowej inwentaryzacji emisji (BEI). Jej celem jest wyliczenie ilości $\mathrm{CO}_{2}$ wyemitowanego wskutek zużycia energii na terenie miasta w roku bazowym. BEl pozwala zidentyfikować główne antropogeniczne źródła emisji $\mathrm{CO}_{2}$ oraz odpowiednio zaplanować i uszeregować pod względem ważności środki jej redukcji. Władze lokalne mogą uwzględnić w inwentaryzacji także emisje $\mathrm{CH}_{4}$ oraz $\mathrm{N}_{2} \mathrm{O}$. Będzie to zależało od tego, czy planują przeznaczyć środki na redukcję także tych gazów cieplarnianych, jak również od wybranego rodzaju wskaźników emisji (standardowe lub LCA). Należy uwzględnić następujące rodzaje źródeł emisji:

- źródła emisji liniowej to przede wszystkim główne trasy komunikacyjne przebiegające na terenie danej strefy, w której dokonuje się oceny wielkości emisji;

- źródła emisji powierzchniowej to obszary zwartej zabudowy mieszkaniowej (jedno- i wielorodzinnej) z indywidualnymi źródłami ciepła, małe zakłady produkcyjne oraz obiekty użyteczności publicznej wraz z drogami lokalnymi; są źródłem niskiej emisji;

- źródła emisji punktowej to emitory jednostek organizacyjnych o znaczącej emisji zanieczyszczeń do powietrza, oddziałujące na obszar objęty analizą.

Sporządzenie BEI ma kluczowe znaczenie, gdyż stanowi ona instrument umożliwiający władzom lokalnym pomiar efektów zrealizowanych przez nie działań związanych z ochroną klimatu. BEI pokaże punkt wyjścia oraz postępy w realizacji przyjętego celu redukcyjnego. Kontrolną inwentaryzację emisji (MEI) sporządza się z wykorzystaniem tych samych metod i tych samych reguł co BEI. Inwentaryzacje emisji są bardzo ważne także z punktu widzenia podtrzymania motywacji wszystkich stron pragnących wesprzeć władze lokalne w realizacji celów gospodarki niskoemisyjnej, gdyż pozwalają im zobaczyć rezultaty ich wysiłków.

Przykłady wskaźników emisji:

- ilość $\mathrm{CO}_{2}$ wyemitowanego na każdą MWh zużytego oleju ( $\mathrm{tCO}_{2} / \mathrm{MWhfuel);}$

- ilość $\mathrm{CO}_{2}$ wyemitowanego na każdą MWh zużytej energii elektrycznej ( $\mathrm{tCO}_{2} /$ MWhe);

- ilość $\mathrm{CO}_{2}$ wyemitowanego na każdą MWh zużytej energii cieplnej ( $\mathrm{tCO}_{2}$ / MWhheat).

Co do zasady, bazową inwentaryzację emisji $\mathrm{CO}_{2}$ sporządza się na podstawie końcowego zużycia energii na terenie miasta/gminy, zarówno w sektorze komunalnym, jak i pozakomunalnym. Władze lokalne mogą jednak uwzględnić w swojej inwentaryzacji także te emisje, które nie są bezpośrednio związane ze zużyciem energii.

W zakres BEI wchodzą zatem następujące rodzaje emisji:

a) emisje bezpośrednie ze spalania paliw w budynkach, instalacjach oraz sektorze transportu;

b) emisje pośrednie towarzyszące produkcji energii elektrycznej, ciepła i chłodu wykorzystywanych przez odbiorców końcowych zlokalizowanych na terenie miasta/gminy;

c) pozostałe emisje bezpośrednie występujące na terenie miasta/gminy.

Punkty a) i c) dotyczą emisji, które fizycznie występują na terenie miasta/gminy. Ich uwzględnienie w BEl jest zgodne z zasadami IPCC, stosowanymi przez kraje będące sygnatariuszami Ramowej konwencji Narodów Zjednoczonych w sprawie zmian klimatu (UNFCCC) i Protokołu z Kioto. Punkt b) dotyczy natomiast emisji, które powstają w związku z produkcją energii elektrycznej, ciepła i chłodu wykorzystywanych na terenie miasta/gminy. Uwzględnia się je w BEI/MEI niezależnie od lokalizacji zakładów wytwarzających wymienione nośniki energii (w granicach lub poza granicami miasta/gminy). 


\subsection{Wdrażanie gospodarki niskoemisyjnej na terenach zurbanizowanych}

Wdrażanie gospodarki niskoemisyjnej na terenach zurbanizowanych jest procesem złożonym, wymagającym jednoczesnego uwzględnienia wielu aspektów rozwoju zgodnie z lokalną specyfiką. W gestii władz miasta pozostaje stworzenie odpowiednich planów i strategii działania, które będą służyły osiąganiu tych celów. Dotyczy to zwłaszcza budownictwa, transportu publicznego i źródeł zaopatrzenia w energię, ale nie bez znaczenia są również kwestie związane z funkcjonowaniem obiektów użyteczności publicznej (przedszkoli, szkół, szpitali, urzędów), gospodarka odpadami, gospodarka wodno-ściekowa, oświetlenie miejsc publicznych. Sukces nie będzie możliwy bez ścisłej współpracy z mieszkańcami i przedsiębiorcami. Zwrot ku niskoemisyjnemu rozwojowi miasta wymaga efektywnego wspierania wzorców zrównoważonej produkcji i konsumpcji, które muszą stać się integralną częścią lokalnego rozwoju. Dla samorządów oznacza to konieczność przeprowadzenia rachunków długookresowych kosztów i korzyści różnych działań inwestycyjnych lub ich zaniechania - uwzględniających także koszty i korzyści społeczne i przyrodnicze - w odniesieniu do będących w gestii władz samorządowych obszarów i obiektów. W szczególności chodzi o:

- wskazanie podmiotów - współuczestnictwo podmiotów będących producentami i/lub odbiorcami energii, ze szczególnym uwzględnieniem działań w sektorze publicznym;

- wskazanie działań - skoncentrowanie się na działaniach niskoemisyjnych i efektywnie wykorzystujących zasoby w określonej perspektywie czasowej, z wyszczególnieniem zadań inwestycyjnych;

- zachowanie spójności z innymi planami/dokumentami własnymi, regionalnymi, krajowymi i UE.

Działania na rzecz gospodarki niskoemisyjnej dzielimy na inwestycyjne, nieinwestycyjne i wspomagające. Zadania inwestycyjne związane z gospodarką niskoemisyjną w miastach w szczególności dotyczą:

- opracowania systemu ewidencjonowania emisji wraz z odpowiednią bazą danych;

- modernizacji różnych typów budynków (nowych, starych wymagających renowacji, użyteczności publicznej, historycznych);

- budowy lub modernizacji oświetlenia miejsc publicznych, budynków mieszkalnych i użytkowych;

- produkcji energii elektrycznej i cieplnej (profilu energetycznego miasta);

- transportu (infrastruktura i tabor);

- budowy i/lub modernizacji systemu ogrzewania/chłodzenia sieciowego;

- prowadzenia gospodarki odpadami;

- prowadzenia gospodarki wodno-ściekowej;

- zakupu urządzeń biurowych.

Zadania nieinwestycyjne obejmują zwłaszcza:

- inwentaryzację emisji;

- planowanie miejskie, w tym planowanie przestrzenne, planowanie rewitalizacji itp.;

- strategie transportowe.

Zadania wspomagające obejmują:

- stworzenie odpowiednich procedur w zamówieniach publicznych niepozwalających pominąć kryteriów emisji zanieczyszczeń w specyfikacji warunków zamówienia; 
- szkolenia pracowników;

- promowanie działań na rzecz gospodarki niskoemisyjnej wśród mieszkańców i przedsiębiorców.

Po dokonaniu prawidłowej identyfikacji inwentaryzacji źródeł emisji i jej wielkości można przystąpić do planowania sposobów przejścia na gospodarkę niskoemisyjną. W tym zakresie można wykorzystać znany z praktyki zarządzania cykl Deminga Plan-Do-Study-Act (PDSA), który zakłada ciągłe doskonalenie w działaniu. W praktyce obejmuje on cztery etapy:

1) Planowanie (Plan): planowanie każdej zmiany z wyprzedzeniem. Przeanalizowanie obecnej sytuacji oraz potencjalnych skutków zmian, zanim podjęte zostaną jakiekolwiek działania. Przemyślenie z góry, co należy zmierzyć, aby przekonać się, czy zamiar został zrealizowany. Pomiar powinien być jednym z elementów realizacji zmiany. Opracowanie planu wdrożenia zmiany, zadbanie o obsadę tego przedsięwzięcia właściwym personelem oraz zaangażowanie właścicieli procesów.

2) Wykonanie (Do): przejście do wdrożenia zmian (pilotażowo może być w mniejszej skali, np. w dzielnicy).

3) Zbadanie (Study): przeprowadzenie gruntownej analizy rezultatów. Wyprowadzenie wniosków na temat tego, co zebrane dane mówią o skuteczności próbnego wdrożenia.

4) Działanie/zastosowanie (Act): podjęcie właściwych działań, aby wdrożyć standard takiego procesu, który wytworzył rezultaty najbardziej pożądane.

Wyzwaniem dla ambitnych jest osiągnięcie tzw. neutralności węglowej. Oznacza ona zerowy ślad węglowy, który osiąga się poprzez odchodzenie od technologii odpowiedzialnych za wysokie emisje gazów cieplarnianych na rzecz niskoemisyjnych, a w odniesieniu do pozostałej emisji stosowanie działań kompensacyjnych, które będą prowadziły do usuwania $\mathrm{CO}_{2} \mathrm{z}$ atmosfery (np. poprzez sekwestrację, sadzenie lasów lub zakup jednostek redukcji emisji, czyli tzw. kredytów węglowych).

Sekwestracja dwutlenku węgla (Carbon Capture and Storage - CCS) jest to proces polegający na wychwytywaniu i bezpiecznym składowaniu $\mathrm{CO}_{2}$, który w innym przypadku byłby wyemitowany do atmosfery i w niej pozostał. Istnieje kilka technologii pozwalających otrzymać skoncentrowany strumień $\mathrm{CO}_{2}$. Takie strumienie dwutlenku węgla mogą być następnie składowane. Także w tym zakresie istnieje szereg możliwości technicznych. Budzą one jednak obawy, głównie co do bezpieczeństwa takiego składowania. Ponadto są kosztowne i energochłonne. Warto jednak pamiętać, że w Unii Europejskiej sekwestracja $\mathrm{CO}_{2}$ została ujęta w dyrektywie w sprawie geologicznego składowania dwutlenku węgla [Dyrektywa CCS 2009/31/ WE] i stanowi część pakietu klimatyczno-energetycznego. Dlatego poszukując sposobów osiągnięcia neutralności węglowej, można rozważać również sekwestrację $\mathrm{CO}_{2}$. Rada Europejska wezwała państwa członkowskie i Komisję Europejską do „działań na rzecz intensyfikacji badań i rozwoju oraz opracowania niezbędnych ram technicznych, gospodarczych i regulacyjnych, by - o ile to możliwe jeszcze przed 2020 r. - wprowadzić w nowych elektrowniach na paliwa kopalne bezpieczne z punktu widzenia środowiska naturalnego wychwytywanie dwutlenku węgla i jego sekwestrację" [KOM(2009)236, s. 4].

Pojedynczy kredyt węglowy reprezentuje jedną tonę metryczną zanieczyszczenia węglowego. Poniewaź środowisko reaguje na sumę emisji gazów cieplarnianych, to miejsce emisji $\mathrm{CO}_{2}$ nie ma tu żadnego znaczenia. Podobnie jest z redukcją emisji. Dlatego można wdrażać projekty ochrony klimatu z dala od miejsc powstawania emisji, np. w krajach rozwijających się, a potwierdzone odpowiednimi certyfikatami efekty tych działań mogą trafić na rynek kredytów węglo- 
wych. Zakup kredytu węglowego kompensuje lub neutralizuje pewną ilość $\mathrm{CO}_{2}$ wyemitowaną przez dany podmiot. Takim podmiotem może być również miasto, z terenu którego nie można w całości wyeliminować emisji gazów cieplarnianych, lecz można je zneutralizować przez zastosowanie środków ochrony środowiska w innych rejonach świata. Jeden kredyt węglowy to certyfikat pozwalający jego właścicielowi legalnie uwolnić jedną tonę dwutlenku węgla do atmosfery. Kredyty węglowe stanowią ważne narzędzie w osiąganiu celów polityki klimatycznej, a ich rynek wykazuje wysoką dynamikę wzrostu. Wyróżnia się dwa rodzaje rynków kredytów węglowych: pierwszy z nich jest dostępny dla państw sygnatariuszy Protokołu z Kioto, drugi obejmuje kredyty dobrowolne, na którym klientami są pozostałe podmioty, najczęściej korporacje zainteresowane demonstrowaniem społecznej odpowiedzialności biznesu. Z raportu Powrót do Przyszłości. Stan dobrowolnych rynków węglowych w 2011 r. [Peters-Stanley i in., 2011] wynika, że w 2010 r., według danych emitentów, sprzedano 131,2 miliona ton metrycznych odpowiedników $\mathrm{CO}_{2}\left(\mathrm{MtCO}_{2} \mathrm{e}\right)$, o 34\% więcej niż w 2009 roku. Do 2015 roku emitenci przewidują rozwój rynku do poziomu rzędu $406 \mathrm{MtCO}_{2 \mathrm{e}}$. Oznaczałoby to, że kredyty węglowe będą w obecnym dziesięcioleciu należeć do grupy najpopularniejszych towarów. Szacuje się, że obroty na rynku kredytów węglowych wzrosną do 3 trylionów euro w roku 2020. Dobrowolne kredyty węglowe są sprzedawane i kupowane na międzynarodowym rynku przez deweloperów, handlarzy i maklerów. Aby jednostki dobrowolnego zmniejszenia emisji (Verified Emission Reduction - VER) zyskały wartość rynkową, muszą zostać zweryfikowane przez wiarygodną, niezależną organizację. Bez odpowiedniej klasyfikacji i rejestracji nie będą one przedstawiały żadnej wartości rynkowej. VER są kredytami węglowymi generowanymi dzięki rozlicznym projektom prowadzonym przez bardzo różne podmioty, od społeczności lokalnych poczynając, na wielkich inwestorach w OZE kończąc. Należy je odróżniać od wprowadzonych przez Protokół z Kioto jednostek poświadczonej redukcji emisji (Certified Emissions Reduction - CER), które są przedmiotem obrotu na rynku obowiązkowym (międzypaństwowym). Są tańsze od CER, gdyż nie muszą sprostać tak rygorystycznym wymaganiom jak jednostki będące przedmiotem obrotu między państwami. Stanowią jednak atrakcyjną opcję dla innych podmiotów, które są zainteresowane ograniczaniem własnej presji na klimat, w tym osiąganiem neutralności węglowej.

Miastem, które oficjalnie ogłosiło, że będzie pierwszą na świecie neutralną węglowo stolicą, jest Kopenhaga. Decyzję w tej sprawie podjęto w 2008 roku, wyznaczając termin osiągnięcia stanu neutralności węglowej na 2025 rok. Burmistrz Kopenhagi Frank Jensen podkreśla, że korzyści będą dotyczyć nie tylko klimatu, ale także mieszkańców miasta, którzy zyskają dzięki czystszemu powietrzu, mniejszej emisji hałasu, łatwiejszemu dostępowi do zielonej infrastruktury i powstaniu nowych miejsc pracy. Transformacja w kierunku neutralności węglowej jest realizowana w ścisłej współpracy sektora publicznego i prywatnego. Obejmie między innymi: instalację nowych turbin wiatrowych i paneli słonecznych, zamianę paliw kopalnych na biomasę w elektrowniach, zwiększenie mobilności rowerowej, inwestycje w hybrydowe autobusy w transporcie publicznym, termomodernizację starych budynków i budowę nowych zgodnie z najwyższymi standardami efektywności energetycznej. W latach 1995-2012 w mieście osiągnięto już redukcję emisji o 40\%. Tylko na 2013 rok przewidziano w budżecie 100 mln USD na inicjatywy służące ochronie klimatu. Przewiduje się, że ponad połowa inwestycji służących poprawie efektywności energetycznej w szkołach, ośrodkach kultury, domach mieszkalnych i biurach zostanie spłacona poprzez oszczędności operacyjne do 2025 roku. Mieszkańcy Kopenhagi mogą liczyć w przyszłości na miesięczne oszczędności w ich rachunkach za 
elektryczność i ogrzewanie o wartości 50-75 USD. Silny sektor zielonej gospodarki stworzy nowe szanse zatrudnienia i rozwoju.

Neutralność węglowa miasta - przykład Kopenhagi

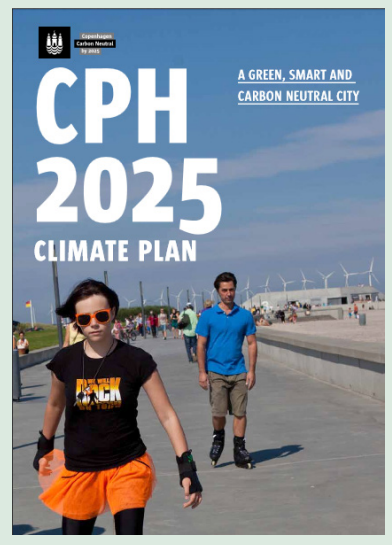

Osiągnięcie w 2025 r. neutralności węglowej przez Kopenhagę jest wspólnym planem polityków, władz miasta, przedsiębiorców i mieszkańców.

Kluczowe są cztery obszary:

- konsumpcja energii;

- produkcja energii;

- mobilność;

- inicjatywy władz miasta.

Plan ma charakter holistyczny - wysiłki na rzecz zmniejszenia konsumpcji energii są ściśle powiązane ze zmianami w jej produkcji, wysoki stopień integracji musi także istnieć między sektorem energetycznym a obszarem transportu. Inwestycje inicjowane przez administrację miasta mają stać się źródłem wartości dodanej poprzez zielone, inteligentne i zdrowe inicjatywy odpowiadające potrzebom i oczekiwaniom mieszkańców. Postawiono na przyciągnięcie inwestycji zagranicznych z zielonego sektora i stworzenie środowiska stymulującego rozwój innowacyjnych rozwiązań.

Źródto: opracowanie własne na podstawie CPH 2025 Climate Plan.

\subsection{Działania na rzecz wdrażania gospodarki niskoemisyjnej w mieście}

Rozwój gospodarki niskoemisyjnej jest procesem rozciągniętym w czasie, wymagającym działania na wielu polach jednocześnie i zaangażowania możliwie wszystkich grup interesariuszy, polegającym na ustawicznym dążeniu do poprawy efektów w zakresie emisji gazów cieplarnianych. Kluczowe znaczenie dla osiągnięcia pożądanych redukcji emisji $\mathrm{CO}_{2}$ mają działania związane z zarządzaniem energią, środowiskiem zabudowanym i transportem, powiązane z odpowiednim oddziaływaniem na zachowania konsumpcyjne i produkcyjne mieszkańców i przedsiębiorców.

Jak wiadomo, redukcja emisji $\mathrm{CO}_{2}$ i innych gazów cieplarnianych jest ściśle związana ze zmianami w tzw. miksie energetycznym miasta w kierunku ograniczania spaIania paliw kopalnych i zwiększania udziału OZE. Innymi słowy, wymaga odpowiedniego zarządzania energią w mieście. Prawidłowo przygotowana strategia wymaga określenia struktury zużycia energii i emisji $\mathrm{CO}_{2}$ z podziałem na sektory oraz nośniki energii i wyznaczenia pożądanej ewolucji tego systemu. Wielkości należy podać w wartościach bezwzględnych i per capita. Pod bezpośrednią kontrolą władz miasta znajdują się poziom zużycia energii i jego zmiany w sektorze komunalnym z podziałem na podsektory (budynki i urządzenia, transport publiczny, oświetlenie publiczne, gospodarka odpadami, gospodarka ściekami itp.) oraz nośniki energii. To od władz zależy wybór wiodących nośników energii, sposób dostarczenia ciepła (chłodu) oraz dbałość o efektywność wykorzystania energii w przestrzeni miejskiej. Analiza kluczowych zmiennych (np. typ konstrukcji, rodzaj ogrzewania, rodzaj klimatyzacji 
i wentylacji, sposób utrzymania i konserwacji, wykorzystanie energii słonecznej do podgrzewania wody, wdrażanie najlepszych praktyk i in.) może pomóc w identyfikacji potencjału oszczędzania energii i poprawy efektywności energetycznej w sieci przesyłowej, budynkach, instalacjach, oświetleniu publicznym itd. Ważnym elementem jest infrastruktura energetyczna obejmująca zakłady produkujące energię elektryczną oraz ciepło (chłód), sieć dystrybucji energii elektrycznej i gazu oraz sieć ciepłowniczą. Istnienie na obszarach zurbanizowanych rozproszonych indywidualnych źródeł ciepła jest przyczyną powstawania szkodliwych niskich emisji, co utrudnia wdrażanie gospodarki niskoemisyjnej. Dlatego niezbędne jest możliwie pełne podłączenie budynków mieszkalnych i użyteczności publicznej do miejskich sieci ciepłowniczych w celu eliminacji licznych palenisk domowych i lokalnych kotłowni. Wymaga to ścisłej współpracy z mieszkańcami oraz stosowania odpowiednich zachęt, także finansowych, dla indywidualnych odbiorców. W wielu krajach stosuje się w tym celu dotacje i/lub ulgi podatkowe. Ograniczenie zużycia paliw kopalnych jest możliwe albo poprzez wzrost efektywności ich wykorzystania, albo przez przejście na OZE.

Wykorzystanie odnawialnych źródeł energii (OZE) na terenach zurbanizowanych i w bezpośredniej ich bliskości stanowi ważny czynnik rozwoju gospodarki niskoemisyjnej. W polskim Prawie energetycznym OZE zdefiniowano jako „źródło wykorzystujące w procesie przetwarzania energię wiatru, promieniowania słonecznego, geotermalną, fal, prądów i pływów morskich, spadku rzek oraz energię pozyskiwaną z biomasy, biogazu wysypiskowego, a także biogazu powstałego w procesach odprowadzania lub oczyszczania ścieków albo rozkładu składowanych szczątek roślinnych i zwierzęcych".

Z zacytowanej definicji wynika, że odnawialnych źródeł energii jest rzeczywiście sporo, można wręcz powiedzieć, że różne formy energii odnawialnej są wszechobecne w środowisku wokół nas, a wyzwaniem pozostaje jedynie sprowadzenie tej energii do postaci atrakcyjnej z punktu widzenia ludzkiej cywilizacji, czyli zwłaszcza energii elektrycznej lub cieplnej. Istniejące w tym zakresie możliwości zostały zaprezentowane $w$ tabeli 8.2.

Tabela 8.2. Źródła energii odnawialnej

\begin{tabular}{|c|c|}
\hline \multicolumn{2}{|c|}{ Odnawialne zasoby energetyczne } \\
\hline Rodzaj źródła & Źródło energii i sposób wykorzystania \\
\hline Nieorganiczne & $\begin{array}{l}\text { Promieniowanie słoneczne - energia elektryczna i cieplna } \\
\text { Wiatr - energia elektryczna } \\
\text { Wody geotermalne - energia elektryczna i cieplna } \\
\text { Wody lądowe (zwłaszcza energia spadku wody) - energia elek- } \\
\text { tryczna } \\
\text { Morza i oceany (pływy i fale, różnica temperatur warstw wody) } \\
\text { - energia elektryczna }\end{array}$ \\
\hline Organiczne & $\begin{array}{l}\text { Pochodzenia roślinnego - energia elektryczna i cieplna } \\
\text { Pochodzenia zwierzęcego - energia elektryczna i cieplna }\end{array}$ \\
\hline
\end{tabular}

Źródto: opracowanie własne na podstawie Gronowicz, 2010, s. 15.

Wytwarzanie energii ze źródeł odnawialnych zależy przede wszystkim od lokalnych lub regionalnych uwarunkowań i dlatego dla każdego miasta trzeba odrębnie rozpatrzyć związane z tym możliwości. Cechą niektórych OZE jest ich niestabilność. Największe ryzyka z tym związane dotyczą energii słonecznej, która zmienia się 
w cyklu dobowym i rocznym i zależy także od zachmurzenia oraz energii wiatru. Najbardziej stabilna jest produkcja energii z biomasy, biogazu i biopaliw. W niektórych regionach atrakcyjne może być wykorzystywanie energii wodnej.

\section{Heidelberg - miasto otwarte na innowacje w zakresie technologii energetycznych}

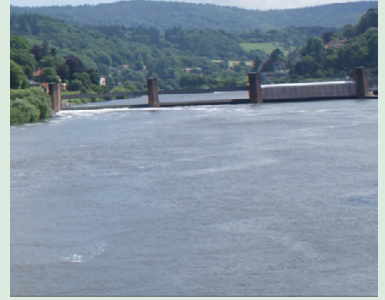

Elektrownia wodna Karlstor, Heidelberg

fot. M. Burchard-Dziubińska
Heidelberg w Niemczech jest przykładem miasta o długiej tradycji historycznej, które od 1992 r. konsekwentnie realizuje działania na rzecz ograniczenia emisji $\mathrm{CO}_{2}$ i zrównoważonego rozwoju. Heidelberg liczy 150 tys. mieszkańców, jest ważnym ośrodkiem akademickim, siedzibą jednego z najstarszych w Europie uniwersytetów (założonego w 1386 r.), ma dobrze zachowaną starówkę z licznymi zabytkami głównie z XVIII w. Włączenie w historyczną tkankę miejską nowoczesnych rozwiązań związanych z wykorzystaniem OZE nie jest w tych warunkach sprawą łatwą. O tym, że jest to wykonalne, świadczy oddana do użytku w 1998 r. elektrownia wodna Karlstor na rzece Neckar. Została zbudowana poniżej góry zamkowej w bezpośredniej bliskości historycznego centrum. Jest to elektrownia podwodna, niewidoczna nad powierzchnią rzeki. Musiała spełnić dwa warunki: nie wpływać na historyczny pejzaż miasta i nie zakłócać żeglugi. Dwie turbiny zostały zatopione w korycie rzeki i dostarczają $16,8 \mathrm{mln}$ kWh energii rocznie. W porównaniu z tradycyjną elektrownią węglową o podobnej mocy elektrownia Karlstor pozwala uniknąć emisji 17000 ton $\mathrm{CO}_{2}$ rocznie.

Źródto: opracowanie na podstawie badań własnych i bttp:/ / wnw.welt.de/print-welt/ article659245/Ein-unterirdisches-Wasserkraftwerk.html [dostęp 13.06.2015].

Warto podkreślić, że na świecie rośnie liczba miast, które podjęły już wyzwanie przejścia w $100 \%$ na OZE. Działania w tym kierunku są coraz chętniej popierane przez mieszkańców. Zajmuje się tym również ogólnoświatowa organizacja obywatelska Avaaz, której misją jest „likwidacja luki między światem, w jakim żyjemy, a światem, jakiego pragnie większość ludzi”. Wynika stąd między innymi poparcie dla powszechnego korzystania z OZE w takich miastach europejskich, jak Frankfurt nad Menem czy Heidelberg, które w perspektywie do 2050 roku chcą wykorzystywać energię wyłącznie ze źródeł odnawialnych. Działania te są wspierane przez niemieckie Ministerstwo Środowiska i Energii Atomowej.

Energia odnawialna produkowana jest zwykle w niewielkich jednostkach wytwórczych zlokalizowanych blisko odbiorcy, co pozwala na podniesienie lokalnego bezpieczeństwa energetycznego oraz zmniejszenie strat przesyłowych. Wytwarzanie energii ze źródeł odnawialnych cechuje niewielka lub zerowa emisja zanieczyszczeń, co zapewnia pozytywne efekty ekologiczne. Ważne są także możliwości rozwoju MŚP i zatrudnienia, jakie stwarzają regionalne i lokalne inwestycje w dziedzinie wytwarzania energii ze źródeł odnawialnych. Znaczny potencjał kryje w sobie upowszechnienie energetyki solarnej, a zwłaszcza fotowoltaiki. Miejskie dachy mogą z czasem zamienić się w minielektrownie. Dotyczy to zarówno obiektów użyteczności publicznej (szpitali, szkół, urzędów), jak i domów mieszkalnych. Korzystnym 
rozwiązaniem jest $w$ tym zakresie ruch prosumencki z powodzeniem rozwijany w wielu krajach europejskich. Atrakcyjne może być również zastosowanie geotermii.

Niektóre z technicznych możliwości korzystania z OZE są specyficzne dla obszarów zurbanizowanych. Może to być przykładowo odzysk energii z sieci wodociągowych czy pozyskiwanie energii ze ścieków. Elektrownie odzyskujące energię z sieci wodociągowej wchodzą w skład infrastruktury technicznej wodociągów publicznych. Nie wywierają wpływu na środowisko naturalne, gdyż energia otrzymywana jest z wody pitnej. Priorytetem pozostaje oczywiście zapewnienie ciągłości dostaw wody odpowiedniej jakości. Dlatego przy tego rodzaju projektach konieczne jest spełnienie bardzo rygorystycznych warunków technologicznych gwarantujących bezpieczeństwo sanitarne. We Włoszech znajduje się ponad sto tego rodzaju elektrowni.

\section{Zielona energia ze ścieków komunalnych}

Grupowa Oczyszczalnia Ścieków w Łodzi ma wła-

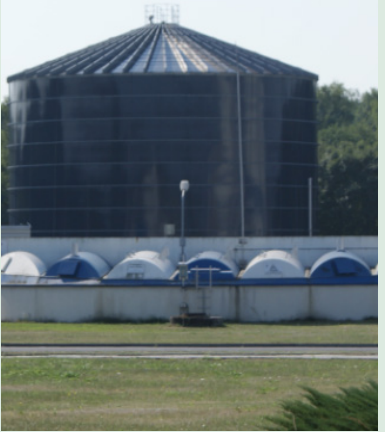

Zbiornik biogazu, Grupowa Oczyszczalnia Ścieków, Łódź fot. M. Burchard-Dziubińska sną elektrociepłownię. Została ona oddana do użytku w 2003 r. i należy do najstarszych tego typu obiektów w Polsce. Spalany w niej biogaz wytwarzany jest w czterech zamkniętych komorach fermentacyjnych o następujących parametrach konstrukcyjnych:

- wysokość $38 \mathrm{~m}$;

- średnica $22 \mathrm{~m}$;

- pojemność czynna $10000 \mathrm{~m}^{3}$ każda.

W instalacji biogazu pracują dwa odsiarczalniki o maksymalnej przepustowości $2 \times 800 \mathrm{~m}^{3} / \mathrm{h}$ pozwalające zredukować zawartość $\mathrm{H}_{2} \mathrm{~S}$ z poziomu 1500 ppm (w gazie nieodsiarczonym) do 150 ppm (w gazie odsiarczonym).

W elektrociepłowni pracują trzy agregaty energii skojarzonej o następujących parametrach:

- moc elektryczna $3 \times 0,933 \mathrm{MW}$

- moc cieplna $3 \times 1,185 \mathrm{MW}$

- maks. zużycie biogazu $3 \times 381 \mathrm{~m}^{3} / \mathrm{h}$

Produkcja ciepła w całości pokrywa potrzeby przedsiębiorstwa, natomiast produkcja energii elektrycznej pokrywa je w ok. 60\%. Są okresy, kiedy nadwyżki sprzedawane są do sieci.

Osady pościekowe również są spalane w kotłowni wyposażonej w trzy kotły olejowo-gazowe o mocy cieplnej 1,4 MW każdy. Uzyskane ciepło wykorzystuje się do suszenia osadów.

Źródto: opracowanie własne na podstawie danych uzyskanych ₹ GOŚ w Łodzi.

W przypadku ścieków potencjalnie możliwym rozwiązaniem jest wykorzystywanie energii wód wypływających z oczyszczalni, ale w tym przypadku ważna jest wysokość spadku wody (piętrzenia). Przy niewielkich wysokościach nie jest to rozwiązanie ekonomicznie opłacalne. Współczesne oczyszczalnie ścieków, zwłaszcza dla dużych miast, są producentem biogazu, który spalany w kogeneracji staje się źródłem energii odnawialnej. W zależności od wielkości oczyszczalni i stosowa- 
nych technologii ilość wytwarzanej energii może przekraczać własne potrzeby przedsiębiorstwa i wówczas nadwyżki są odprowadzane do sieci energetycznej i/lub cieplnej. Zgodnie z obowiązującymi przepisami powstający biogaz musi być spalany. Dlatego produkcja energii w kogeneracji jest najlepszym rozwiązaniem. Wykorzystywać można również gaz wysypiskowy pochodzący z miejskich składowisk odpadów.

Ważnym elementem działań na rzecz rozwoju gospodarki niskoemisyjnej jest opracowywanie i wdrażanie na terenach zabudowanych rozwiązań, które pozwoliłyby stosownie do panującego na danym obszarze klimatu i tradycji architektonicznych realizować projekty odpowiadające potrzebom użytkowników w zgodzie z zasadami zrównoważonego rozwoju. Oznacza to jednoczesne ograniczanie kosztów budowy i eksploatacji obiektów, dbałość o jakość życia użytkowników, respektowanie wymogów ochrony środowiska oraz przestrzeganie standardów zatrudnienia. Warto pamiętać, że budownictwo odpowiada za około $40 \%$ całkowitego końcowego zużycia energii, generując jednocześnie ponad jedną trzecią emisji $\mathrm{CO}_{2}$ w UE. Dzięki coraz bardziej rygorystycznym normom w zakresie efektywności energetycznej budynków będzie możliwe osiągnięcie oszczędności znacznej ilości energii połączone z równoczesnym działaniem na rzecz ograniczania emisji gazów cieplarnianych i rachunków za ogrzewanie i prąd użytkowników obiektów. Podejmowane obecnie we Wspólnocie działania są kontynuacją wcześniejszych regulacji zawartych w dyrektywie 2002/91/WE. Nowa dyrektywa 2010/31/UE, która weszła w życie w lipcu 2010 roku (państwa członkowskie zostały zobowiązane do transpozycji dyrektywy do prawa krajowego do 9 lipca 2012 r.) reguluje między innymi kwestie charakterystyki energetycznej budynków zarówno nowo wybudowanych, jak i już istniejących: sprzedawanych, wynajmowanych lub podlegających istotnej renowacji (tzn. takiej, której całkowity koszt prac renowacyjnych przekracza 25\% wartości budynku lub modernizacja obejmuje ponad $25 \%$ powierzchni budynku). Minimalne wymagania w zakresie charakterystyki energetycznej budynków powinny być sformułowane przynajmniej w stosunku do: systemów ogrzewania, systemów ciepłej wody użytkowej, systemów klimatyzacji oraz dużych systemów wentylacyjnych (lub kombinacji tych systemów) niezależnie od wielkości obiektu. Generalnym celem działań jest wdrożenie minimalnych wymagań w dziedzinie charakterystyki energetycznej budynków i modułów budynków, aby dojść do optymalnego poziomu kosztów w całym cyklu życia obiektu. Należy przeprowadzić dwa rodzaje obliczeń: z perspektywy społecznej lub makroekonomicznej uwzględniające koszt emisji $\mathrm{CO}_{2}$, ale z wyłączeniem wszystkich należnych podatków oraz z punktu widzenia inwestora, bez uwzględnia kosztów emisji $\mathrm{CO}_{2}$, ale z uwzględnieniem zobowiązań podatkowych odbiorców końcowych. W celu obliczenia optymalnego kosztu na poziomie makroekonomicznym państwa członkowskie muszą dodatkowo ustalić koszt emisji gazów cieplarnianych, który odzwierciedla kwantyfikowany, pieniężny i zdyskontowany koszt ekwiwalentu $\mathrm{CO}_{2}$ w okresie obliczeniowym. Rozporządzenie określa następujące minimalne wartości: 20 euro za tonę ekwiwalentu $\mathrm{CO}_{2}$ od 2025 do 2030 roku; 35 euro za tonę ekwiwalentu $\mathrm{CO}_{2}$ od 2025 do 2030 roku i 50 euro za tonę ekwiwalentu $\mathrm{CO}_{2}$ po 2030 roku.

Państwa członkowskie muszą określić co najmniej dziewięć budynków referencyjnych. Dla każdego z trzech rodzajów budynków (tj. budynek jednorodzinny, budynek wielorodzinny i budynek biurowy) wymagane jest wskazanie trzech budynków referencyjnych - jednego w przypadku nowych budynków oraz dwóch w przypadku budynków istniejących mających przejść gruntowny remont. Budynki referencyjne powinny odzwierciedlać typowe krajowe budynki nowe lub istniejące, odpowiednio dla każdej kategorii. Preferowanym działaniem jest głęboka termomodernizacja, 
tzn. oparta na podejściu całościowym z uwzględnieniem charakterystyki zużycia energii budynków oraz włączenia technologii pozyskiwania energii ze źródeł odnawialnych.

Nowością jest wprowadzenie pojęcia budynku o niemal zerowym zużyciu energii. Odnosi się do tych obiektów, które w procesie eksploatacji zużywają niewielką ilość energii pochodzącej w dużym stopniu ze źródeł odnawialnych, w tym energii wytwarzanej na miejscu lub w pobliżu. Dyrektywa nie podaje jednoznacznych, liczbowych kryteriów, które pozwoliłyby zaklasyfikować budynek do kategorii obiektów „o niemal zerowym zużyciu energii”. Państwa członkowskie zostały zobowiązane do przygotowania takiej definicji we własnym zakresie, uwzględniając lokalną specyfikę. Ponadto mają opracować krajowe plany realizacji tego celu. Dokument ten ma zawierać między innymi definicję budynków zużywających energię na poziomie bliskim zeru, sposoby promocji budownictwa zeroemisyjnego wraz z określeniem nakładów finansowych na ten cel, a także szczegółowe krajowe wymagania dotyczące zastosowania energii ze źródeł odnawialnych w obiektach nowo wybudowanych i modernizowanych. Znowelizowana dyrektywa zobowiązuje państwa członkowskie do doprowadzenia do tego, aby od końca 2020 roku wszystkie nowo powstające budynki były obiektami zeroemisyjnymi. Od 9 lipca 2013 roku wszystkie wybudowane budynki muszą spełniać określone w dyrektywie normy dotyczące minimalnej charakterystyki energetycznej.

$\mathrm{Na}$ świecie certyfikacja budynków pod kątem spełniania coraz bardziej rygorystycznych norm efektywności energetycznej i budownictwa zrównoważonego staje się bardzo popularna. Oto kilka przykładów: LEED: Leadership in Energy and Environmental Design, Stany Zjednoczone 1998; BREEAM: Building Research Establishment Environmental Assessment Method, Wielka Brytania 1990; Green Star, Australia 2003; CASBEE: Comprehensive Assessment System for Building Environmental Efficiency, Japonia 2001; GBTool - międzynarodowy standard opracowany przez International Framework Committee for the Green Building Challenge w 1998 roku i wdrożony w ponad 25 krajach; DGNB: Deutsche Gesellschaft für Nachhaltiges Bauen, Niemcy 2007. Świadczy to o dostrzeżeniu w tych działaniach istotnego czynnika stymulującego rozwój energooszczędnych gospodarek. Wiele z wyznaczonych kierunków działania ma znaczenie dla obszarów zurbanizowanych. Dotyczy to aktywności inwestycyjnej władz, jak i mieszkańców i działających na tych terenach podmiotów gospodarczych. Przykładowo dyrektywa o efektywności energetycznej obejmuje m.in. następujące wymogi:

- remontowanie rocznie co najmniej 3\% łącznej powierzchni budynków centralnych instytucji rządowych, począwszy od 2014 roku, oraz nabywanie budynków, usług i produktów charakteryzujących się wysoką efektywnością energetyczną;

- ustanowienie krajowych długoterminowych strategii na rzecz promowania inwestycji w remonty budynków mieszkalnych i komercyjnych, a także opracowanie krajowych systemów zobowiązujących do efektywności energetycznej lub równoważnych środków, tak aby zapewnić odbiorcom końcowym oszczędności energii na poziomie $1,5 \%$ rocznie;

- przeprowadzenie do końca 2015 roku oceny możliwości wykorzystania wysokosprawnej kogeneracji oraz wydajnych instalacji centralnego ogrzewania i chłodzenia we wszystkich państwach członkowskich.

Z tych zapisów wynika, że sektor publiczny ma do odegrania bardzo ważną rolę w inicjowaniu zmian w zakresie efektywności energetycznej budynków zarówno użyteczności publicznej, jak i obiektów mieszkalnych, a także odnośnie do produkcji energii do celów grzewczych i chłodzenia. 
Trzecim obszarem tematycznym, który ma istotne znaczenie dla rozwoju gospodarki niskoemisyjnej w miastach, jest transport. Transport miejski odpowiada za około jedną czwartą emisji $\mathrm{CO}_{2}$ z transportu ogółem i $69 \%$ wypadków drogowych. W miastach dokuczliwe są również zatory, zła jakość powietrza i hałas. Dlatego w rozwoju bardziej zrównoważonych systemów transportu miejskiego upatruje się możliwości redukcji emisji zanieczyszczeń powietrza, w tym gazów cieplarnianych, poprawy klimatu akustycznego miasta, a także złagodzenia zjawiska kongestii. Osiągnięcie pozytywnych efektów w tej dziedzinie jest możliwe poprzez działania w zakresie doboru środków transportu, budowy odpowiedniej infrastruktury, obejmującej także drogi rowerowe i przystosowane do ruchu pieszych, stosowanie odpowiednich systemów zarządzania ruchem oraz poprzez poprawę dostępności obywateli do usług transportu zbiorowego. Pozytywne efekty w zakresie eliminacji emisji zanieczyszczeń powietrza można wzmocnić dzięki wymianie taboru na elektryczny, hybrydowy, wodorowy lub zasilany biopaliwami. Wymaga to rozwoju odpowiedniej infrastruktury uzupełniania paliwa czy ładowania pojazdów. Szersze wykorzystywanie flot takich pojazdów mogłoby znacząco wpłynąć nie tylko na redukcję emisji gazów cieplarnianych, ale także na poprawę klimatu akustycznego w miastach. Intensywne prace B+R w zakresie źródeł energii i systemów napędowych w transporcie pozwalają mieć nadzieję, że nowoczesne rozwiązania zostaną szybko wdrożone do praktyki na odpowiednio dużą skalę. Dobre praktyki w tym zakresie w Polsce prezentuje przykładowo firma Nissan, która wprowadziła na rynek udany model pięcioosobowego samochodu elektrycznego nissan leaf, czy Tesla rozbudowująca sieć stacji szybkiego ładowania. Każde miasto musi jednak opracować własne rozwiązania dostosowane do lokalnych potrzeb i specyfiki. Przykładowo Kopenhaga i Amsterdam konkurują ze sobą o miano rowerowej stolicy Europy. Dojazdy rowerem do pracy, szkół czy po zakupy są możliwe dzięki odpowiednio rozwijanej infrastrukturze, która znakomicie podniosła bezpieczeństwo ruchu i skraca czas dojazdu. W Kopenhadze aż $80 \%$ rowerzystów korzysta z rowerów nawet zimą, gdyż jest zasadą dokładne oczyszczanie ścieżek rowerowych ze śniegu. Najpierw odśnieżane są drogi dla rowerzystów, a dopiero potem dla samochodów. Wyjątkiem są tylko cztery główne arterie, które są oczyszczane równocześnie ze ścieżkami rowerowymi. W Kopenhadze z rowerów korzystają również pracownicy świadczący usługi publiczne (listonosze, rykszarze, mobilni sprzedawcy, policja). Nic dziwnego, że w rankingach miast przyjaznych rowerom używa się „indeksu kopenhagizacji” (Copenhagenize Index).

Coraz chętniej wytycza się w miastach strefy ograniczonej emisji (Low Emission Zone -LEZ). Są to obszary, do których możliwy jest wjazd tylko i wyłącznie pojazdami spełniającymi określone normy emisji spalin. Wprowadzenie stref ograniczonej emisji komunikacyjnej jest jednym z instrumentów zmniejszenia wielkości emisji liniowej, zwłaszcza w dużych aglomeracjach. Obecnie w Europie funkcjonuje 225 Stref Ograniczonej Emisji w 15 krajach [http://urbanaccessregulations.eu].

Działania na rzecz niskoemisyjnego transportu obejmują także: inicjatywy mające na celu promocję transportu publicznego, ruchu rowerowego oraz ruchu pieszego, wprowadzenie samochodu publicznego i popularyzację car sharing (niekomercyjne wypożyczanie samochodów) i car pooling (wspólne dojazdy samochodem np. do pracy). Na kształtowanie nawyków transportowych mieszkańców można wpływać, wykorzystując szeroką gamę instrumentów: bezpośrednich (np. zakazy wjazdu), jak i pośrednich (np. opłaty za wjazd do określonej strefy, płatne parkingi dla samochodów, a bezpłatne dla rowerów, bezpłatne ładowanie samochodów elektrycznych) (zob. EkoMiasto\#Gospodarka, rozdział Ekologistyka i transport zrównoważony). 
Działania wspomagające rozwój gospodarki niskoemisyjnej w mieście wymagają zaangażowania szerokiego grona interesariuszy, zwłaszcza urzędników miejskich, mieszkańców i przedsiębiorców. Kształtowanie odpowiednich zachowań konsumentów i producentów jest procesem, który może być wspomagany przez:

- działania edukacyjne budujące odpowiednią świadomość, dostarczające umiejętności i wiedzy specjalistycznej z zakresu techniki (np. w obszarze efektywności energetycznej, wykorzystania odnawialnych źródeł energii, efektywnego transportu itd.), zarządzania projektami, zarządzania danymi, zarządzania finansami;

- stosowanie zielonych zamówień publicznych;

- wykorzystanie instrumentów ekonomicznych stymulujących pożądane zachowania podmiotów ekonomicznych (opłaty, ulgi podatkowe, subwencje, kary finansowe);

- wykorzystanie instrumentów przymusu bezpośredniego (zakazów, nakazów, norm i standardów).

Łączne oddziaływanie na wszystkich tych polach powinno doprowadzić do rozwoju rynków produktów i usług cechujących się wysoką efektywnością energetyczną, niską emisyjnością gazów cieplarnianych, nowoczesnym wzornictwem, atrakcyjnością z punktu widzenia budowania silnej pozycji konkurencyjnej. Dodatkową nagrodą będzie możliwość pracy i życia w lepszym, bardziej przyjaznym środowisku.

\section{Bibliografia}

Biała księga transportu (2011), Urząd Publikacji Unii Europejskiej, Luksemburg.

Budowa gospodarki niskoemisyjnej. Podręcznik dla regionów, INTERREG IVC, http://documents.rec.org/publications/RSC_BuildingLow_carbonEconomy_PL_Dec2011. pdf.

Dyrektywa Parlamentu Europejskiego i Rady 2008/50/WE z dnia 21 maja 2008 r.

Dyrektywa Parlamentu Europejskiego i Rady 2009/125/WE z dnia 21 października 2009 r. ustanawiająca ogólne zasady ustalania wymogów dotyczących ekoprojektu dla produktów związanych z energią (wersja przekształcona).

Dyrektywa Parlamentu Europejskiego i Rady 2009/125/WE z dnia 21 października 2009 r. ustanawiająca ogólne zasady ustalania wymogów dotyczących ekoprojektu dla produktów związanych z energią.

Dyrektywa Parlamentu Europejskiego i Rady 2009/28/WE z dnia 23 kwietnia 2009 r. w sprawie promowania stosowania energii ze źródeł odnawialnych zmieniająca i w następstwie uchylająca dyrektywy 2001/77/WE oraz 2003/30/WE.

Dyrektywa Parlamentu Europejskiego i Rady 2009/29/WE z dnia 23 kwietnia 2009 r. zmieniająca dyrektywę 2003/87/WE w celu usprawnienia i rozszerzenia wspólnotowego systemu handlu uprawnieniami do emisji gazów cieplarnianych.

Dyrektywa Parlamentu Europejskiego i Rady 2009/31/WE z 23 kwietnia 2009 r. w sprawie geologicznego składowania dwutlenku węgla oraz zmieniająca dyrektywę Rady 85/337/EWG, Euratom, dyrektywy Parlamentu Europejskiego i Rady 2000/60/WE, 2001/80/WE, 2004/35/WE, 2006/12/WE, 2008/1/WE i rozporządzenie (WE) Nr 1013/2006 (Dz. U. L 140 z 5 czerwca 2009 r.).

Dyrektywa Parlamentu Europejskiego i Rady 2010/31/UE z dnia 19 maja 2010 r. w sprawie charakterystyki energetycznej budynków.

Dyrektywa Parlamentu Europejskiego i Rady 2012/27/UE z 25 października 2012 r. w sprawie efektywności energetycznej. 
Dyrektywa Parlamentu Europejskiego i Rady 2009/31/WE z dnia 23 kwietnia 2009 r. w sprawie geologicznego składowania dwutlenku węgla oraz zmieniająca dyrektywę Rady 85/337/EWG, Euratom, dyrektywy Parlamentu Europejskiego i Rady 2000/60/WE, 2001/80/WE, 2004/35/WE, 2006/12/WE, 2008/1/WE i rozporządzenie (WE) nr 1013/2006.

Koc D., Węglarz A., Wnuk R., Głęboka termomodernizacja. Polska Mapa drogowa 2050. Analiza źródet literaturowych WP4, Krajowa Agencja Poszanowania Energii S.A. http://www.renowacja2050.pl/files/publikacje/ies_2.pdf [dostęp 14.07.2015].

Kociołek-Balawejder E., Stanisławska E. (2012), Chemia środowiska, Wydawnictwo Uniwersytetu Ekonomicznego we Wrocławiu, Wrocław.

Komunikat Komisji dla Rady, Parlamentu Europejskiego, Europejskiego Komitetu Ekonomiczno-Społecznego i Komitetu Regionów Promowanie zrównoważonego wykorzystania zasobów: Strategia tematyczna w sprawie zapobiegania powstawaniu odpadów i ich recyklingu, Bruksela, 21.12.2005, COM(2005)666 końcowy.

Kurczewski P., Lewandowska A. (2008), Zasady prośrodowiskowego projektowania obiektów technicznych dla potrzeb zarządzania ich cyklem życia, Wydawnictwo KMB Druk, Poznań.

Peters-Stanley M., Hamilton K., Marcello T., Sjardin M. (2011), Back to the Future State of the Voluntary Carbon Markets, 2011 06/02/2011, Ecosystem Marketplace and Bloomberg New Energy Finance.

Plan działania na rzecz racjonalizacji zużycia energii: sposoby wykorzystania potencjału, $\operatorname{COM}(2006) 0545$.

Review of evidence on health aspects of air pollution - REVIHAAP Project (2013), WHO Regional Office for Europe, http://www.euro.who.int/en/health-topics/environment-and-health/air-quality/publications/2013/review-of-evidence--on-health-aspects-of-air-pollution-revihaap-project-final-technical-report [dostęp 10.07.2015].

Rozporządzenie Komisji (UE) NR 82/2013 z dnia 14 sierpnia 2013 r. zmieniające załącznik III do rozporządzenia Parlamentu Europejskiego i Rady (UE) r 6/2010 w sprawie oznakowania ekologicznego UE.

Staniaszek D., Głęboka termomodernizacja. Polska Mapa Drogowa 2050. Koszty optymalne, Buildings Performance Institute Europe, http://www.renowacja2050.pl/ files/publikacje/ies_3.pdf [dostęp 12.07.2015].

Transformacja w kierunku gospodarki niskoemisyjnej w Polsce 2011, Bank Światowy, Departament Walki z Ubóstwem i Zarządzania Gospodarką.

Ustawa Prawo energetyczne z dn. 10 kwietnia 1997 r., Dz.U. z 1997 r. Nr 54, poz. 348. 


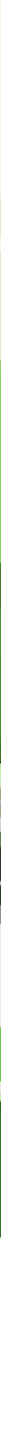

